\title{
Ozone production during the field campaign RISFEX 2003 in the sea of Japan: analysis of sensitivity and behaviour based on an improved indicator
}

\author{
Z. Q. Wang, Y. S. Chen, B. Qi, and B. Yang \\ Key Laboratory of Applied Surface and Colloid Chemistry (Shaanxi Normal University), Ministry of Education, \\ School of Chemistry and Materials Science, Xian 710062, China
}

Received: 2 April 2010 - Published in Atmos. Chem. Phys. Discuss.: 21 April 2010

Revised: 16 August 2010 - Accepted: 13 September 2010 - Published: 11 October 2010

\begin{abstract}
The ratio $\Phi=k_{\mathrm{HC}+\mathrm{OH}}[\mathrm{HC}] / k_{\mathrm{NO}_{\mathrm{x}}+\mathrm{OH}}\left[\mathrm{NO}_{\mathrm{x}}\right]$ is used as an indicator for the sensitivity of ozone production $\left(P\left(\mathrm{O}_{3}\right)\right)$ to $\mathrm{HC}$ and $\mathrm{NO}_{\mathrm{x}}$ in the field campaign RISFEX 2003 (RIShiri Fall EXperiment 2003) at Rishiri Island $\left(45.07^{\circ} \mathrm{N}, 141.12^{\circ} \mathrm{E}\right.$, and $35 \mathrm{~m}$ a.s.l. $)$ in the sea of Japan during September 2003. Four different sensitivity regimes are obtained based on the indicator. The sensitivity is found to show a distinctive pattern in each regime. In Regime I $(\Phi<1), P\left(\mathrm{O}_{3}\right)$ almost linearly increases with increasing $\mathrm{HC}$ and almost linearly decreases with increasing $\mathrm{NO}_{\mathrm{x}}$. In Regime II $(1<\Phi<9 \pm 5)$, there is a less-than-linear increase in $P\left(\mathrm{O}_{3}\right)$ with $\mathrm{HC}$ and a less-than-linear decrease with $\mathrm{NO}_{\mathrm{x}} \cdot P\left(\mathrm{O}_{3}\right)$ less-than-linearly increases with both $\mathrm{HC}$ and $\mathrm{NO}_{\mathrm{x}}$ in Regime III $(9 \pm 5<\Phi<45 \pm 7)$, and near linearly increases with $\mathrm{NO}_{\mathrm{x}}$ and is nearly constant with increasing HC in Regime IV ( $\Phi>45 \pm 7)$. During the campaign, 91 percent of $P\left(\mathrm{O}_{3}\right)$ data appear in Regime III and IV, indicating that $\mathrm{NO}_{\mathrm{x}}$ is a limiting factor of ozone production. Hence, it may be an efficient strategy to control $\mathrm{NO}_{\mathrm{x}}$ emission for ozone abatement at the site.

Comparisons between the observed $P\left(\mathrm{O}_{3}\right)$ and the ones modelled have represented general agreement. However, the model tends to underestimate $P\left(\mathrm{O}_{3}\right)$ in Regime II, implying that an important source of peroxy radicals is possibly missed. In Regime IV, the modelled $P\left(\mathrm{O}_{3}\right)$ is systematically larger than the measured one under a low $j\left(\mathrm{O}^{1} \mathrm{D}\right)$ condition, which may be caused by the over-estimated yields of peroxy radicals from the reactions of monoterpenes with ozone. A budget analysis indicates that sensitivity of $P\left(\mathrm{O}_{3}\right)$ is declining with $\mathrm{HC}$ and enhancing with $\mathrm{NO}$ when the condition
\end{abstract}

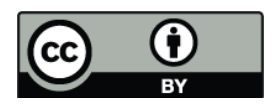

Correspondence to: $\mathrm{B}$. Qi (b.qi@163.com) shifts from Regime II to Regime IV, which is also observed through the analysis of $P\left(\mathrm{O}_{3}\right)$ sensitivity using $\Phi$. Sensitivity studies for $P\left(\mathrm{O}_{3}\right)$ are conducted to determine the effect of $\mathrm{NO}_{\mathrm{x}}$ and monoterpenes on ozone production and the conclusions are very consistent with those derived from the indicator. This study demonstrates that the ratio $\Phi$ could be a useful index to ascertain the sensitivity of $P\left(\mathrm{O}_{3}\right)$ to $\mathrm{HC}$ and $\mathrm{NO}_{\mathrm{x}}$ in the clean marine boundary layer.

\section{Introduction}

Tropospheric ozone is a major constituent of air pollution which is detrimental to humans and vegetation (WMO, 1999). Ozone is also a greenhouse gas in the upper troposphere and has an important impact on the radiative balance of the atmosphere (Brasseur et al., 1998). The concentration of surface ozone in the Northern Hemisphere has increased by a factor of 2 and more in average since the preindustrial era (Bojkov et al., 1988). Previously, it is assumed that tropospheric ozone comes from the stratosphere. However, recent work has shown that a large fraction of the tropospheric ozone is due to in situ photochemical production in rural and remote environments (Chameides and Walker, 1973; Fishman and Crutzen, 1977, 1978; Liu et al., 1980, 1987; Logan, 1985, 1998; Monks et al., 2000). High tropospheric ozone has been a great problem in many parts of the world (Frank et al., 2001). To develop effective abatement strategies, it is necessary to investigate whether the ozone production is controlled by $\mathrm{HC}$ (hydrocarbons, which contains $\mathrm{CH}_{4}$ and $\mathrm{CO}$ as well as anthropogenic and biogenic hydrocarbons), $\mathrm{NO}_{\mathrm{x}}$ or both. 
Essential for the ozone formation is the cycle of odd hydrogen (odd $\mathrm{H}$ ) which can be defined as the sum of $\mathrm{OH}, \mathrm{HO}_{2}$ and $\mathrm{RO}_{2}$ (Kleinman et al., 1986, 1991). During daytime, sources of hydroxyl radicals are the photolysis of ozone, of nitrous acid, of aldehydes and ozonolysis of alkenes which can be an important $\mathrm{OH}$ source in rural areas (Platt et al., 1986; Alicke et al., 2003; Paulson et al., 1996; Ariya et al., 2000). These formation paths lead to daytime $\mathrm{OH}$ levels in the range of several $10^{6} \mathrm{~cm}^{-3}$ (Hein et al., 1997; Holland et al., 1998, 2003; Andreas et al., 2003). OH radical reacts with inorganic and organic species to oxidize them, leading to $\mathrm{HO}_{2}$ and a variety of organic peroxy radicals which can react with $\mathrm{NO}$ to convert it to $\mathrm{NO}_{2}$ :

$$
\begin{aligned}
& \mathrm{OH}+\mathrm{CO} \rightarrow \mathrm{HO}_{2}+\mathrm{CO}_{2} \\
& \mathrm{OH}+\mathrm{VOC} \rightarrow \mathrm{RO}_{2}+\mathrm{H}_{2} \mathrm{O} \\
& \mathrm{RO}_{2}+\mathrm{NO} \rightarrow \mathrm{HO}_{2}+\mathrm{R}^{\prime} \mathrm{O}_{2}+\mathrm{NO}_{2}+\text { oxygenate VOC } \\
& \mathrm{HO}_{2}+\mathrm{NO} \rightarrow \mathrm{NO}_{2}+\mathrm{OH}
\end{aligned}
$$

The conversion of $\mathrm{NO}$ to $\mathrm{NO}_{2}$ and the subsequent photolysis of $\mathrm{NO}_{2}$ drive the ozone production:

$$
\begin{aligned}
& \mathrm{NO}_{2}+h v \rightarrow \mathrm{O}\left({ }^{3} \mathrm{P}\right)+\mathrm{NO} \\
& \mathrm{O}\left({ }^{3} \mathrm{P}\right)+\mathrm{O}_{2} \rightarrow \mathrm{O}_{3}
\end{aligned}
$$

The reaction of $\mathrm{OH}$ with $\mathrm{NO}_{2}$ provides a stable product and removes $\mathrm{OH}$ from the system:

$$
\mathrm{OH}+\mathrm{NO}_{2} \rightarrow \mathrm{HNO}_{3}
$$

The reactions of peroxy radicals with peroxy radicals also remove peroxy radicals from the system:

$$
\begin{aligned}
& \mathrm{HO}_{2}+\mathrm{RO}_{2} \rightarrow \mathrm{ROOH}+\mathrm{O}_{2} \\
& \mathrm{HO}_{2}+\mathrm{HO}_{2} \rightarrow \mathrm{H}_{2} \mathrm{O}_{2}+\mathrm{O}_{2}
\end{aligned}
$$

During the odd hydrogen cycle, $P\left(\mathrm{O}_{3}\right)$ sensitivity greatly depends on the indirect competition between Reactions (R7) and (R8) as sinks for odd hydrogen radicals (Sillman, 1995, 1997). As a result, the ratio between the products from Reactions (R8b) and (R7), the afternoon $\mathrm{H}_{2} \mathrm{O}_{2} / \mathrm{HNO}_{3}$, has been used as an indicator to ascertain ozone sensitivity (Sillman, 1995). However, the indicator is based on long-lived species and, thus, can only reflect the past sensitivity of the investigated air parcel (Frank et al., 2001). This makes it difficult to determine the local controlling factor of ozone formation, which is necessary for the development of abatement strategies. Therefore, we propose a new parameter $\Phi$ as an indicator to determine the instantaneous sensitivity of ozone production, which is defined as:

$$
\begin{aligned}
\Phi & =k_{\mathrm{HC}+\mathrm{OH}}[\mathrm{HC}][\mathrm{OH}] / k_{\mathrm{NO}_{\mathrm{x}}+\mathrm{OH}}\left[\mathrm{NO}_{\mathrm{x}}\right][\mathrm{OH}] \\
& =k_{\mathrm{HC}+\mathrm{OH}}[\mathrm{HC}] / k_{\mathrm{NO}_{\mathrm{x}}+\mathrm{OH}}\left[\mathrm{NO}_{\mathrm{x}}\right]
\end{aligned}
$$

where $k_{\mathrm{HC}+\mathrm{OH}}$ and $k_{\mathrm{NO}_{\mathrm{x}}+\mathrm{OH}}$ are the combined rate coefficient for the reactions of $\mathrm{OH}$ radical with $\mathrm{HC}$ and $\mathrm{NO}_{\mathrm{x}}$, respectively. $[\mathrm{HC}],[\mathrm{NO}]$ and $\left[\mathrm{NO}_{2}\right]$ are the concentrations of $\mathrm{HC}, \mathrm{NO}$ and $\mathrm{NO}_{2}$, respectively. As (R8) rely on the level of peroxy radicals which is closely related to Reactions (R1) and (R2), the parameter $\Phi$ reflects the relative size of two major sinks of odd hydrogen (Reactons R7 and R8) and, thus, is a valid indicator of $P\left(\mathrm{O}_{3}\right)$ sensitivity. Moreover, it is not based on photochemically produced long-lived species, but describes the instantaneous feature of an air parcel. So, $\Phi$ is a more suitable tool for developing ozone abatement strategies.

The parameter $\Phi$ is consistent with the indicator $\Theta$ proposed by (Frank et al., 2001), which is defined as the ratio of the lifetimes of $\mathrm{OH}$ against the losses by reacting with VOCs and $\mathrm{NO}_{\mathrm{x}}$. If the concentrations of $\mathrm{HC}$ except $\mathrm{CH}_{4}$ and $\mathrm{CO}$ are used to calculate the value of $\Phi$, there exists a reciprocal relation between the values of $\Phi$ and $\Theta$. The addition of $\mathrm{CH}_{4}$ and $\mathrm{CO}$ in our work is because both of them can react with $\mathrm{OH}$ radical to produce peroxy radicals $\left(\mathrm{CH}_{3} \mathrm{O}_{2}\right.$ for $\mathrm{CH}_{4}$ and $\mathrm{HO}_{2}$ for $\mathrm{CO}$ ), which are similar with other VOC species.

In this paper, we investigate $\Phi$ as an improved indicator to determine the sensitivity of ozone production to $\mathrm{HC}$ and $\mathrm{NO}_{\mathrm{x}}$ and to analyse the behaviour of $P\left(\mathrm{O}_{3}\right)$ in different sensitive regions using the data from the RISFEX 2003 campaign. Furthermore, model studies based on Regional Atmospheric Chemistry Modelling (RACM) (Stockwell et al., 1997) are used to test the robustness of the indicator.

\section{Experimental}

The measurements were conducted at an observatory (Rishiri Island Observatory, RIO) $\left(45.07^{\circ} \mathrm{N}, 141.12^{\circ} \mathrm{E}, 35 \mathrm{~m}\right.$ a.s.l. $)$ built on Rishiri Island, which is a round, dormant, volcanic island with a diameter of ca. $15 \mathrm{~km}$ and ca. $20 \mathrm{~km}$ northwest of Hokkaido in the sea of Japan. In its center stands a $1721 \mathrm{~m}$ high mountain covered by a coniferous forest on its slope. RIO is situated on a foothill of the mountain ca. $800 \mathrm{~m}$ away from the shore (Fig. 1). The population on the island is ca. 7500 and the local pollution can be negligible (Tanimoto et al., 2000). A previous study at Rishiri Island has shown that the site receives the air masses usually from the clean Arctic, West Siberia and Pacific region as well as from polluted Japan and continental Asia (Tanimoto et al., 2000).

In the observatory, there are two 2-m high containers used for housing instruments and the inlets for trace gas and aerosol measurements. Peroxy radicals were measured by PERCA technique (Cantrell et al., 1982). The inlet of the PERCA instrument was mounted on the top of a container. $\mathrm{NO}$ and $\mathrm{NO}_{2}$ were measured by a chemiluminescence instrument with a photolytic converter (CLD770AL and PLC760, Eco Physics). The detection limits for NO and $\mathrm{NO}_{2}$ measurements were 22 and $45 \mathrm{pptv}(\mathrm{S} / \mathrm{N}=2,1$-min measurement time), respectively. $\mathrm{O}_{3}$ was measured by a 


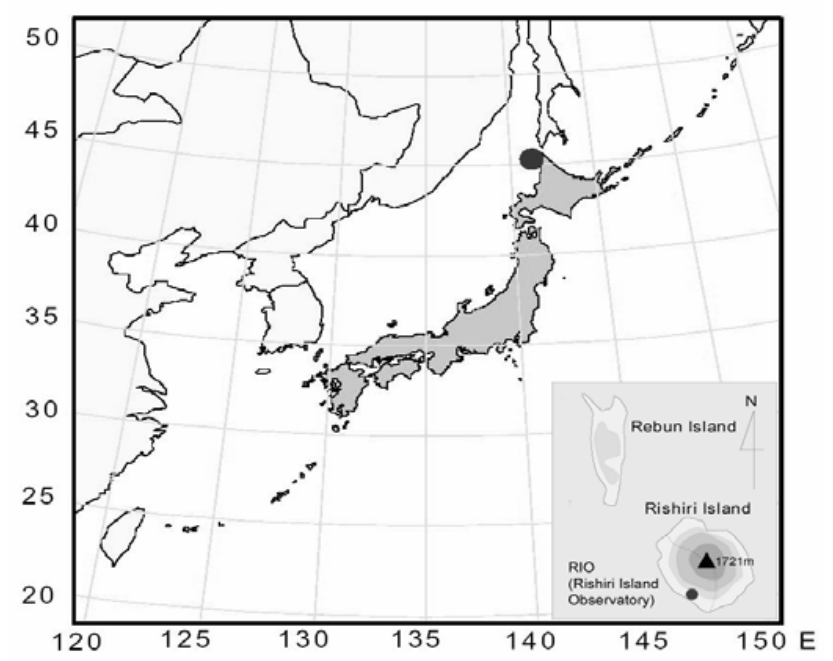

Fig. 1. Geographical location of Rishiri Island and Rishiri Island Observatory.

commercial UV absorption analyser (49C, Thermo). CO was measured with a non-dispersive infrared (NDIR) photometer instrument (48C, Thermo). Black carbon was measured with a commercial instrument based on absorption photometry (AE-21, Magee Scientific). Non-methane hydrocarbons (NMHCs) were measured by GC-FID and GCMS followed by sampling the air into canisters. HCHO, $\mathrm{CH}_{3} \mathrm{CHO}$, acetone, toluene and monoterpenes were measured by proton-transfer reaction-mass spectrometry (PTRMS). Speciation and quantification of monoterpenes were made with two GC-based instruments. The solar actinic flux and photolysis frequency of $\mathrm{O}_{3}$ to $\mathrm{O}\left({ }^{1} \mathrm{D}\right)\left(j\left(\mathrm{O}^{1} \mathrm{D}\right)\right)$ and $\mathrm{NO}_{2}$ to $\mathrm{NO}\left(j\left(\mathrm{NO}_{2}\right)\right)$ were measured by an actinic flux spectral radiometer ( $\mathrm{GmbH}$, Meteorologie Consult). Temperature, relative humidity, pressure, and wind direction and speed were recorded with conventional meteorological instruments. A further detailed description of the measurements and instruments has been given elsewhere (Qi et al., 2007).

\section{Model}

A time-dependent box model based on Regional Atmospheric Chemistry Modelling (RACM) (Stockwell et al., 1997) is developed to describe the remote marine boundary layer (MBL) chemistry and to determine the production rate of ozone. Kinetic rate constants are updated using the results in Sander et al. (2003). The model is also updated by incorporating more detailed monoterpenes chemistry (Kanaya et al., 2002a). The running of the model is constrained by measured stable chemical species, photolysis frequencies and meteorological parameters with the integrations conducting each day for 24 $\mathrm{h}$ starting at 00:00 and ending 24:00 JST (Japan standard time) at 10-min intervals given the measure- ment data available. If time resolution of the measurements is greater or less than once every $10 \mathrm{~min}$, averaging or linear interpolation will be used to calculate the input data. Other unmeasured oxygenated hydrocarbon species are initially set to zero when each calculation is started and are allowed to accumulate with time integration. The calculations are performed for a 10-min-period with the integral time of $\sim 15 \mathrm{~min}$ to ensure that the concentrations of major radicals $\left(\mathrm{HO}_{2}, \mathrm{OH}\right.$ and $\mathrm{RO}_{2}$ ) have reached an approximate steady state. In daytime, the $1 \sigma$ uncertainty of the model, based on the combined uncertainties in the kinetic rate coefficients and in the measured concentrations of species, is estimated using a Monte Carlo approach to be ca. $\pm 30 \%$ (Carslaw et al., 1999).

\section{Result and discussion}

\subsection{Ozone production rate $\left(P\left(\mathrm{O}_{3}\right)\right)$ during the campaign}

The ozone production rate, $P\left(\mathrm{O}_{3}\right)$, can be approximately determined by the rate at which $\mathrm{NO}$ is oxidized to $\mathrm{NO}_{2}$ by the reactions with peroxy radicals (Kleinman et al., 1995):

$$
P\left(\mathrm{O}_{3}\right)=k[\mathrm{NO}]\left(\left[\mathrm{HO}_{2}\right]+\left[\mathrm{RO}_{2}\right]\right)
$$

where $k$ is a combined rate coefficient for the oxidation of $\mathrm{NO}$ to $\mathrm{NO}_{2}$ by all peroxy radicals. In this approach, the minor pathway of the higher organic peroxy radicals which lead to the formation of organic nitrates and the loss of $\mathrm{NO}_{2}$ by reaction with $\mathrm{OH}$ are neglected, thus, Eq. (2) represents an upper limit for $P\left(\mathrm{O}_{3}\right)$ (Mihelcic et al., 2003).

During RISFEX2003, the data coverage allows for the determination of $P\left(\mathrm{O}_{3}\right)$ during 18-21 September. The daytime weather during this period is typically clear in the morning hours (06:00-11:00 JST), and scattered clouds frequently appear overhead at noon and in the afternoon as shown in Fig. 2d. The daytime is defined as the interval of $j\left(\mathrm{O}^{1} \mathrm{D}\right)>1 \times 10^{-7} \mathrm{~s}^{-1}$, corresponding to time from 06:00 to 18:00 JST. The local wind direction at the site is dominated by the south in daytime and shifts to the north in the night, exhibiting typical land-sea breeze.

We estimate the values of $P\left(\mathrm{O}_{3}\right)$ using the observed $\mathrm{HO}_{2}$ and $\mathrm{RO}_{2}$ concentration. The time series of observed $P\left(\mathrm{O}_{3}\right)$ together with pertinent chemical species and physical parameters in 10-min averages are shown in Fig. 2. We can see from Fig. 2a that $P\left(\mathrm{O}_{3}\right)$ varies greatly between these days, with midday values (10-min average) varying from 0.4 to $2.5 \mathrm{ppbv} / \mathrm{hr}$. The scatter in $P\left(\mathrm{O}_{3}\right)$ is primarily caused by NO, since NO is more variable than $\mathrm{RO}_{\mathrm{x}}$. The high $P\left(\mathrm{O}_{3}\right)$ occurring on 18 September is due to both high NO and peroxy radical levels. The daily mean $P\left(\mathrm{O}_{3}\right)$ for all data determined in this work is $0.93 \mathrm{ppbv} / \mathrm{hr}$, similar to reported values obtained in MBL (Salisbury et al., 2002; Monks et al., 1998; Fleming et al., 2006). Figure $2 \mathrm{~b}$ shows that $\mathrm{RO}_{\mathrm{x}}$ (the sum of $\mathrm{HO}_{2}$, $\mathrm{RO}_{2}$ and $\mathrm{OH}$ radicals) signals increase quickly in the early 

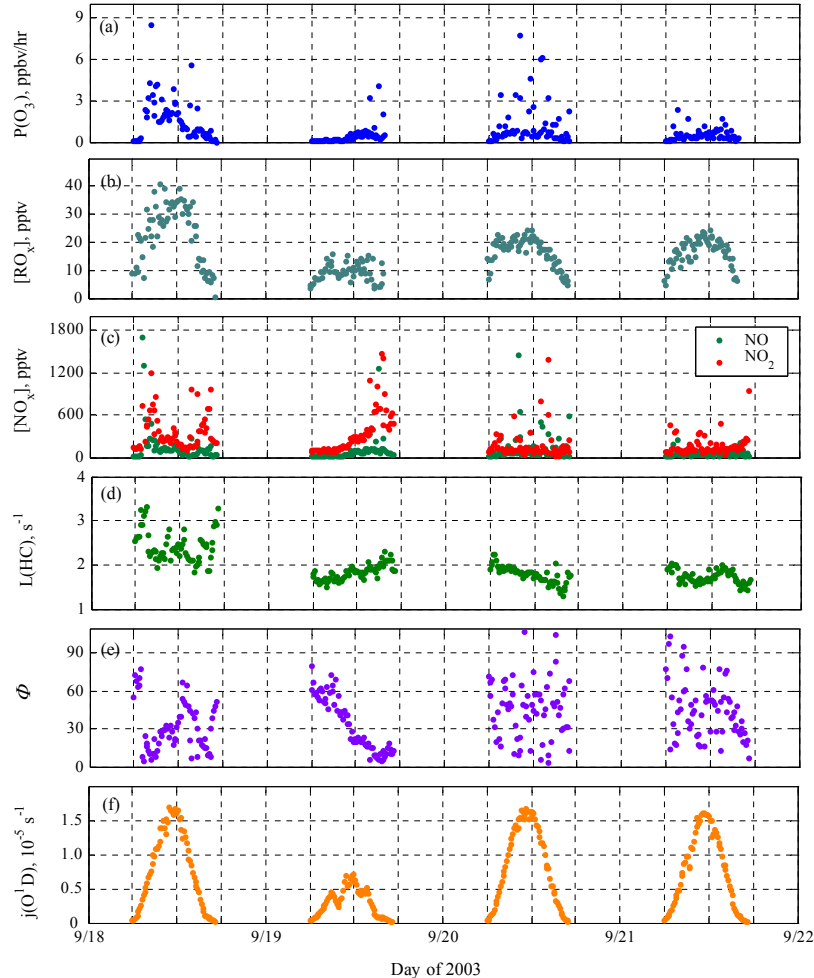

Fig. 2. Time series of (a) ozone production rate $\left(P\left(\mathrm{O}_{3}\right)\right)$, (b) $\mathrm{RO}_{\mathrm{x}}$, (c) $\mathrm{NO}_{\mathrm{x}}\left(\mathrm{NO}\right.$ and $\left.\mathrm{NO}_{2}\right)$, (d) $\mathrm{OH}$ reactivity due to $\mathrm{HC}(L(\mathrm{HC}))$, (e) $\Phi$ and (f) $j\left(\mathrm{O}^{1} \mathrm{D}\right)$ in 10-min averages during 18-21 September 2003.

morning on clear-sky days, and reach a peak at $\sim 11: 50$ JST. In the afternoon, the radical signals decay consistently with the attenuation of UV radiation flux. In contrast, little variation is observed on the cloudy day (19 September). This suggests that the production of peroxy radicals is strongly driven by photochemistry, same as the previous observations in MBL (Burkert et al., 2001; Carpenter et al., 1997). The value of $\Phi$, calculated using the observed data of $\mathrm{HC}$ species and $\mathrm{NO}_{\mathrm{x}}$ concentrations, varies in the range of 3.5 107.2, with no distinct diurnal variation (Fig. 2e). The averaged values and ranges of measured chemical species and meteorological parameters are listed in Table 1.

\subsection{Sensitivity of $\mathrm{P}\left(\mathrm{O}_{3}\right)$ to $\mathrm{HC}$ and $\mathrm{NO}_{x}$}

Figure 3 shows the dependence of observed $P\left(\mathrm{O}_{3}\right)$ on $\Phi$. A modelled trend of $P\left(\mathrm{O}_{3}\right)$ with increasing $\Phi$ is also shown in Fig. 3, which is similar to the variation of observed $P\left(\mathrm{O}_{3}\right)$. The running of the model is under the condition that the concentrations of all chemical species, except for $\mathrm{NO}$ and $\mathrm{NO}_{2}$, and physical parameters are constrained to those measured at 11:50 JST of 18 September. With the ratio of $\mathrm{NO}$ to $\mathrm{NO}_{2}$ invariable, we change the concentrations of $\mathrm{NO}$ and $\mathrm{NO}_{2}$ to obtain a series of different $\Phi$ in the range of $0.01-1000$.

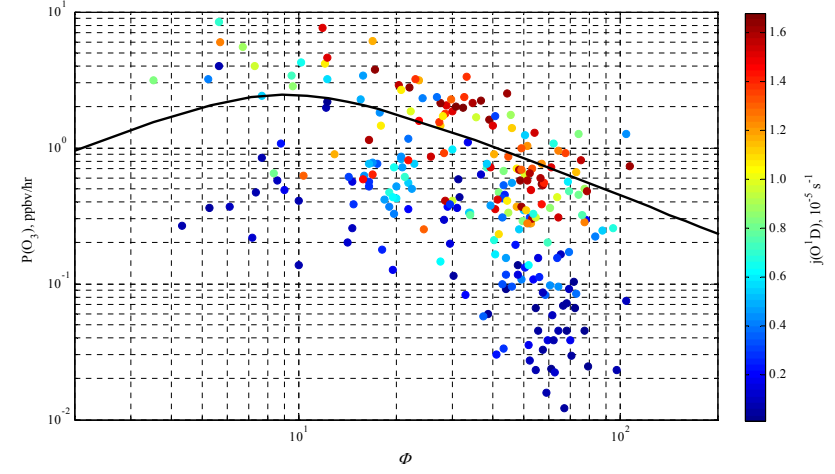

Fig. 3. Dependence of $P\left(\mathrm{O}_{3}\right)$ on the indicator $\Phi$ for daytime 10min averaged data during 18-21 September 2003. The colour of the dots shows the values of $j\left(\mathrm{O}^{1} \mathrm{D}\right)$. The black curve shows the modelled trend of $P\left(\mathrm{O}_{3}\right)$ with increasing $\Phi$ at 11:50 JST of 18 September.

As Fig. 3 shows, the variation of $P\left(\mathrm{O}_{3}\right)$ can be divided into two different trends as $\Phi$ changes. Under low $\Phi$ conditions, $P\left(\mathrm{O}_{3}\right)$ increases as $\Phi$ increases, indicating a positive correlation between $P\left(\mathrm{O}_{3}\right)$ and $\Phi$. When $\Phi$ rises to a critical value, denoted as $\Phi_{\text {opt }}, P\left(\mathrm{O}_{3}\right)$ reaches the maximum amount in the process of the continual increase of $\Phi$. At $\Phi>\Phi_{\mathrm{opt}}, P\left(\mathrm{O}_{3}\right)$ is found to be negatively correlated with $\Phi$.

To investigate the sensitivity of $P\left(\mathrm{O}_{3}\right)$ in different $\Phi$ regions, we also calculate the relative sensitivity of $P\left(\mathrm{O}_{3}\right)$ to $\mathrm{NO}$ and $\mathrm{HC}, d \ln P\left(\mathrm{O}_{3}\right) / d \ln [\mathrm{NO}]$ and $d \ln P\left(\mathrm{O}_{3}\right) / d \ln [\mathrm{HC}]$, which were found to be equal to:

$$
\begin{aligned}
& d \ln P\left(\mathrm{O}_{3}\right) / d \ln [\mathrm{NO}]=\left(1-3 / 2 L_{\mathrm{N}} / Q\right) /\left(1-1 / 2 L_{\mathrm{N}} / Q\right) \\
& d \ln P\left(\mathrm{O}_{3}\right) / d \ln [\mathrm{HC}]=\left(1 / 2 L_{\mathrm{N}} / Q\right) /\left(1-1 / 2 L_{\mathrm{N}} / Q\right) \\
& Q=2 k_{1}\left[\mathrm{HO}_{2}\right]^{2}+2 k_{2}\left[\mathrm{HO}_{2}\right]\left[\mathrm{RO}_{2}\right]+L_{\mathrm{R}}+L_{\mathrm{N}}
\end{aligned}
$$

where $k_{1}$ and $k_{2}$ are rate constants for the reactions of $\mathrm{HO}_{2}+\mathrm{HO}_{2}$ and $\mathrm{HO}_{2}+\mathrm{RO}_{2}$, respectively. $L_{\mathrm{R}}$ represents all radical other radical reactions including $\mathrm{HO}+\mathrm{HO}_{2}$ and $\mathrm{RO}_{2}+\mathrm{R}^{\prime} \mathrm{O}_{2}, L_{\mathrm{N}}$ denotes all radical loss reactions between free radicals and $\mathrm{NO}$ or $\mathrm{NO}_{2}$ including $\mathrm{HO}+\mathrm{NO}_{2} \rightarrow \mathrm{HNO}_{3}$ and $\mathrm{RO}_{2}+\mathrm{NO} \rightarrow$ organic nitrate (Kleinman et al., 1997). The concentrations of peroxy radicals used in the calculations are from the model. The values of $P\left(\mathrm{O}_{3}\right), d \ln P\left(\mathrm{O}_{3}\right) / d \ln [\mathrm{NO}]$ and $d \ln P\left(\mathrm{O}_{3}\right) / d \ln [\mathrm{HC}]$ are simultaneously shown in Fig. 4. As shown in Fig. 4, it is clear that the sensitivity of $P\left(\mathrm{O}_{3}\right)$ to $\mathrm{HC}$ and $\mathrm{NO}_{\mathrm{x}}$ can be divided into four different regions (labelled as Regime I, II, III and IV, respectively). In Regime I, $P\left(\mathrm{O}_{3}\right)$ almost linearly increases with increasing $\mathrm{HC}$ and almost linearly decreases with increasing $\mathrm{NO}_{\mathrm{x}}$. In Regime II, there is a less-than-linear increase in $P\left(\mathrm{O}_{3}\right)$ with $\mathrm{HC}$ and a less-than-linear decrease with $\mathrm{NO}_{\mathrm{x}} \cdot P\left(\mathrm{O}_{3}\right)$ less-than-linearly increases with both $\mathrm{HC}$ and $\mathrm{NO}_{\mathrm{x}}$ in Regime III, and near linearly increases with $\mathrm{NO}_{\mathrm{x}}$ and is nearly constant with increasing $\mathrm{HC}$ in Regime IV. Comparing the results with previous 
Table 1. Summary of observed $P\left(\mathrm{O}_{3}\right)$ and selected chemical species and parameters $(1 \sigma$ standard deviation given in brackets).

\begin{tabular}{lrrrrrrr}
\hline Itims & \multicolumn{3}{c}{ Day in September } & & & All days \\
& Median & Median & Median & Median & Median & Minimum & Maximum \\
\hline $\mathrm{RO}_{\mathrm{x}}$, pptv & $23.1(10.9)$ & $9.1(3.2)$ & $16.6(5.1)$ & $16.4(4.9)$ & $16.5(8.4)$ & 0.4 & 41.0 \\
$P\left(\mathrm{O}_{3}\right)$, ppbv/hr & $1.6(1.5)$ & $0.4(0.7)$ & $1.1(1.5)$ & $0.5(0.4)$ & $0.9(1.3)$ & 0.0 & 8.5 \\
$\mathrm{NO}$, pptv & $148(257)$ & $74(156)$ & $126(212)$ & $47(43)$ & $99(188)$ & 4 & 1686 \\
$\mathrm{NO}_{2}$, pptv & $375(330)$ & $323(310)$ & $166(203)$ & $156(133)$ & $256(273)$ & 33 & 1462 \\
Isoprene, pptv $_{\mathrm{MACR}, \text { pptv }}$ & $135(69)$ & $47(28)$ & $39(19)$ & $42(20)$ & $66(57)$ & 2 & 356 \\
Toluene, pptv & $259(77)$ & $149(56)$ & $121(46)$ & $129(53)$ & $165(81)$ & 16 & 422 \\
monoterpenes, pptv & $115(43)$ & $79(54)$ & $83(23)$ & $79(42)$ & $89(44)$ & 7 & 306 \\
$\mathrm{O}_{3}$, ppbv & $155(174)$ & $74(52)$ & $93(82)$ & $31(47)$ & $88(111)$ & 1 & 636 \\
$L(\mathrm{HC}), \mathrm{s}^{-1}$ & $26(5)$ & $23(3)$ & $18(1)$ & $27(2)$ & $23(5)$ & 15 & 34 \\
$\Phi^{1}$ & $2.4(0.3)$ & $1.8(0.2)$ & $1.8(0.2)$ & $1.7(0.1)$ & $1.9(0.4)$ & 1.3 & 3.3 \\
$j\left(\mathrm{O}^{1} \mathrm{D}\right), \times 10^{-6} \mathrm{~s}^{-1}$ & $31(19)$ & $33(21)$ & $45(23)$ & $45(22)$ & $38(22)$ & 4 & 107 \\
Temperature, & $7.9(5.7)$ & $2.9(2.1)$ & $8.4(5.8)$ & $7.7(5.5)$ & $6.7(5.4)$ & 0.1 & 16.8 \\
relative humidity, \% & $21(3)$ & $16(1)$ & $17(2)$ & $18(3)$ & $18(3)$ & 11 & 25 \\
\hline
\end{tabular}

studies (Milford et al., 1994; Frank et al., 2001), we notice that the definitions of the regimes are greatly different. Milford et al. (1994) distinguished only between two regimes, and considered that $P\left(\mathrm{O}_{3}\right)$ was $\mathrm{NO}_{\mathrm{x}}$-limited when the value of $d \ln P\left(\mathrm{O}_{3}\right) / d \ln [\mathrm{NO}]$ was larger than $d \ln P\left(\mathrm{O}_{3}\right) / d \ln [\mathrm{HC}]$, otherwise it was HC-limited. From that classification, $P\left(\mathrm{O}_{3}\right)$ is HC-limited in Regime I and, therefore, ozone abatement must rely on the reduction of $\mathrm{HC}$ concentration. However, based on our former analysis, a rise of $\mathrm{NO}_{\mathrm{x}}$ can also reduce the production of ozone in this region. In the work of Frank et al. (2001), $P\left(\mathrm{O}_{3}\right)$ was distinguished between three regimes, and the definitions of Regime II and III were similar with Regime III and IV in our study, respectively. The difference is that they classify Regime I and II (in our work) into one region. Nevertheless, it is clear that the $P\left(\mathrm{O}_{3}\right)$ sensitivity for $\mathrm{HC}$ and $\mathrm{NO}_{\mathrm{x}}$ is completely different in Regime I and Regime II.

In this paper, the border between Regime I and II is fixed as $\Phi=1$ which indicates a comparable competition for $\mathrm{OH}$ between $\mathrm{HC}$ and $\mathrm{NO}_{\mathrm{x}}$. The border between Regime II and III, denoted as $\Phi_{\mathrm{opt}}$, where the maximum $P\left(\mathrm{O}_{3}\right)$ occurs at the given $\mathrm{HC}$ level, is defined as the value of $\Phi$ at which $d \ln P\left(\mathrm{O}_{3}\right) / d \ln [\mathrm{NO}]$ equals to zero. Besides, the border between Regime III and IV is defined as the value of $\Phi$ at which the ratio of $d \ln P\left(\mathrm{O}_{3}\right) / d \ln [\mathrm{HC}]$ to $d \ln P\left(\mathrm{O}_{3}\right) / d \ln [\mathrm{NO}]$ equals to 0.05 . Based on the calculated sensitivity and four defined regimes, there are 24, 127 and 120 data points located in Regime II, III and IV, respectively, while none appears in Regime I during the campaign. It indicates that 91 percent of $P\left(\mathrm{O}_{3}\right)$ data is occurred in Regime III and IV, implying that $\mathrm{NO}_{\mathrm{x}}$ is a limiting factor for ozone production. Hence, the controlling of $\mathrm{NO}_{\mathrm{x}}$ emission may be an efficient strategy for ozone abatement at the site.

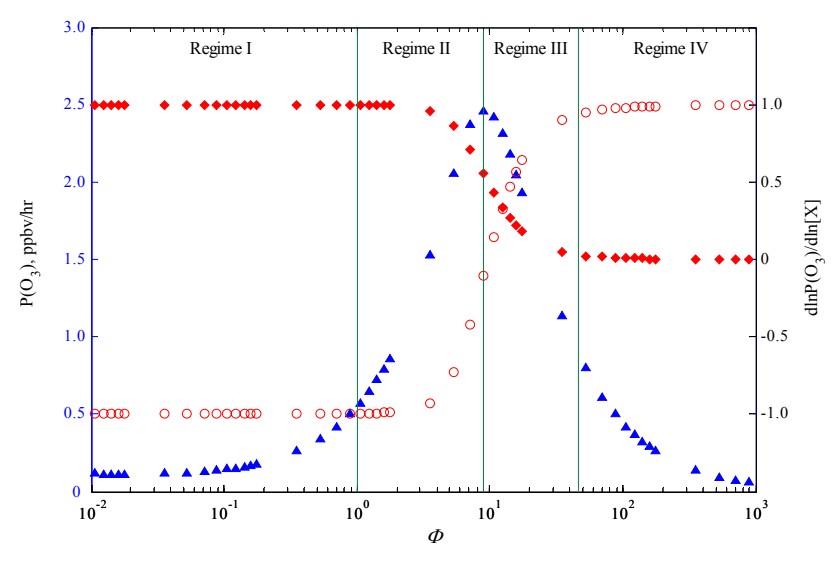

Fig. 4. Dependence of $d \ln P\left(\mathrm{O}_{3}\right) / d \ln [\mathrm{NO}]$ (shown by open circle), $d \ln P\left(\mathrm{O}_{3}\right) / d \ln [\mathrm{HC}]$ (shown by square) and $P\left(\mathrm{O}_{3}\right)$ (shown by triangle) on $\Phi$ at 11:50 JST of 18 September.

During the period of 18-21 September, $\Phi_{\text {opt }}$ is ca. $9 \pm 5$, which is consistent with the results in previous studies (Frank et al., 2001; Tonnesen et al., 2000; Kleinman et al., 2005). The indicator value of $\Phi=9$ is corresponding to a value of 0.20 for $\Theta$ within the range of $0.1-0.3$ reported by Frank et al. (2001) (the contributions of $\mathrm{CO}$ and $\mathrm{CH}_{4}$ to $L(\mathrm{HC})$ is $\sim 46 \%$ which is calculated by the observed data at 11:50 JST of 18 September). At the point of $\Phi=9$, the percentage of $\mathrm{OH}$ reacting with VOCs is about $83 \%$ which is in agreement with the value of $82 \% \sim 86 \%$ published by Tonnesen et al. (2000). From Kleinman et al. (2005), it was found that the maximum $P\left(\mathrm{O}_{3}\right)$ occurred when the ratio of $\mathrm{HC}$ reactivity to $\mathrm{NO}_{\mathrm{x}}$ concentrations was approximately equal to $1 \mathrm{~s}^{-1} \mathrm{ppbv}^{-1}$ which was in the range of $0.9 \sim 3.4 \mathrm{~s}^{-1} \mathrm{ppbv}^{-1}$ corresponding to the 
indicator value of $5 \sim 15$ found in our paper. The value of $\Phi$ at the border between Regime III and IV is ca. $45 \pm 7$, which is greatly lower than the value of $\sim 180(\Theta=0.01)$ proposed by Frank et al. (2001). It implies that the extent of Regime IV in our work is wider than their VOC-insensitive region. The indicator value of $\Phi=45$ is associated with $\sim 100$ pptv NO which is in good agreement with the threshold NO concentration where $\mathrm{HO}_{\mathrm{x}}$ radicals begin at nearly constant with decreasing NO (Kanaya et al., 2002c), which can be considered as a distinctive characteristic of HC-insensitive region (Regime IV).

Figure 5 shows the dependence of calculated $P\left(\mathrm{O}_{3}\right)$ sensitivity and the parameter $L_{\mathrm{N}} / Q$ upon $\Phi$ for daytime 10-min averaged data. The indicator is shown to correlate with the relative sensitivity of $P\left(\mathrm{O}_{3}\right)$ in Fig. 5a, illustrating that it is a valid parameter to reflect $P\left(\mathrm{O}_{3}\right)$ sensitivity. As shown in Fig. $5 b, \Phi$ is fully anti-correlated with the parameter $L_{\mathrm{N}} / Q$ which is a successful indicator for determining the sensitivity of $P\left(\mathrm{O}_{3}\right)$ (Kleinman et al., 2005). Undoubtedly, the indicator $\Phi$ is a more convenient parameter rather than $L_{N} / Q$, as the value of $\Phi$ could be easily measured or calculated (Frank et al., 2001). However, a constant $L_{\mathrm{N}} / Q$ is always associated with a range of $\Phi$ values, as represented in Fig. 5b. It implies that a problem with our indicator is that its correlation with $P\left(\mathrm{O}_{3}\right)$ sensitivity may shift under different conditions, which is similar with previous indicators. Therefore, it is necessary to test the robustness of the indicator.

\subsection{Robustness study of $\Phi$}

As discussed by Frank et al. (2001), the indicator $\Theta$ can be used to find the instantaneous sensitivity regime of an air parcel, in contradistinction to other earlier proposed indicators based on long-lived species. More importantly, it is more robust than the indicators $\mathrm{NO}_{\mathrm{y}}$ and $\mathrm{O}_{3} / \mathrm{NO}_{\mathrm{z}}$ and of comparable robustness as the indicator $\mathrm{H}_{2} \mathrm{O}_{2} / \mathrm{HNO}_{3}$. As an improved parameter based on the indicator $\Theta, \Phi$ naturally inherits the advantages of the original indicator, but it also has the same problem from very high percentages of large alkenes. Fortunately, the studied site is more free from the impact of human activities, thus, the emission of alkenes which are mainly emitted from diesel motors is greatly limited. Therefore, the improved indicator $\Phi$ is suitable for ascertaining the sensitivity of $P\left(\mathrm{O}_{3}\right)$ on this island. Nonetheless, due to the addition of $\mathrm{CH}_{4}$ and $\mathrm{CO}$ concentrations in determining the value of $\Phi$, it is necessary to retest the robustness of the indicator.

Firstly, the model calculations are used to investigate the effect of the atmospheric compositions of VOCs on the variation of $\Phi_{\text {opt }}$. We separately raise the observed concentrations of each VOC species by a factor of 1.5 with holding other VOCs constant to calculate $P\left(\mathrm{O}_{3}\right)$ at different binned $\Phi$ and then to determine the value of $\Phi_{\text {opt }}$. The performance of the calculations is similar with that described in Sect. 4.2. By comparing those $\Phi_{\text {opt }}$ values with the initial $\Phi_{\text {opt }}$ calculated from the observed data, we obtain the changes of
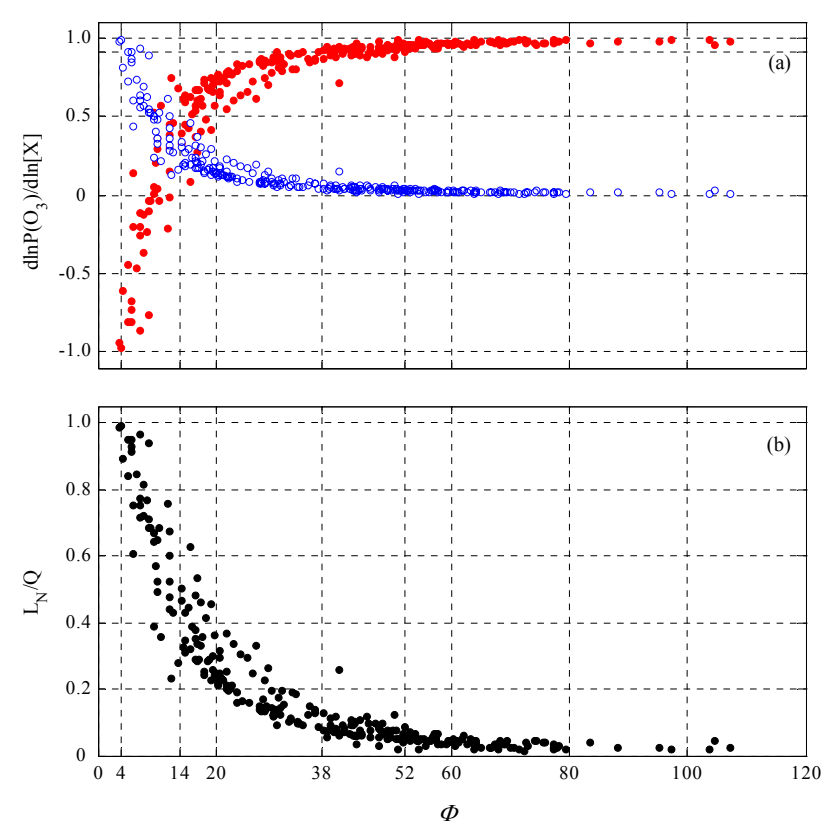

Fig. 5. Dependence of (a) $d \ln P\left(\mathrm{O}_{3}\right) / d \ln [\mathrm{NO}]$ (shown by red dot) and $d \ln P\left(\mathrm{O}_{3}\right) / d \ln [\mathrm{HC}]$ (shown by open blue circle) and (b) $L_{\mathrm{N}} / Q$ on $\Phi$ for daytime 10-min average data during 18-21 September 2003. The ranges of two borders are also labelled in this figure.

$\Phi_{\text {opt }}\left(\Delta \Phi_{\text {opt }}\right)$ due to the increase of VOCs concentrations (Fig. 6). Figure 6a represents the percentage variations of $\Phi_{\text {opt }}$ relative to the initial value. As Fig. 6a shows, the increases of isoprene (ISO) and methacrolein (MACR) have a greater influence on $\Phi_{\text {opt }}$ than other VOCs, leading to a $1.7 \%$ increase and a $1.5 \%$ decrease of $\Phi_{\text {opt }}$, respectively. This is partly attributed to their high fractional contributions to $L(\mathrm{HC})$ ( $25 \%$ for ISO, while $12 \%$ for MACR) which are significantly higher than others (all are less than 5\%). Considering that the fractional contributions of each VOCs to total reactivity are different from each other, we also calculate the changes of $\Phi_{\mathrm{opt}}$ with one unit (ppbv) increase of VOCs (Fig. 6b). From Fig. 6b, it is shown that the increases of ISO, acetaldehyde (ALD), monoterpenes, toluene (TOL) and MACR lead to a great change of $\Phi_{\text {opt }}$. Clearly, the increases of ISO and its oxidation product MACR show adverse effect on $\Phi_{\text {opt }}$, which ensures a relatively constant value of $\Phi_{\text {opt }}$ under conditions with elevated ISO concentration on 18 September. However, TOL from anthropogenic can greatly reduce $\Phi_{\text {opt }}$, illuminating that local $\Phi_{\text {opt }}$ is higher than it in more polluted environments.

Recent studies (Sillman, 1995; Thornton et al., 2002) have implied that the value of $\Phi_{\mathrm{opt}}$, at which the maximum amount of $P\left(\mathrm{O}_{3}\right)$ happens at a fixed level of $\mathrm{HC}$, is closely related to the production rate of odd hydrogen radicals. Sillman (1995) found that the value of $\Sigma k_{\mathrm{OH}} \mathrm{HC} / \mathrm{NO}_{\mathrm{x}}$ at which the transition from $\mathrm{NO}_{\mathrm{x}}$-sensitive to $\mathrm{HC}$-sensitive conditions occurred, corresponding to $\Phi_{\mathrm{opt}}$ in our work, was anti-correlate to 

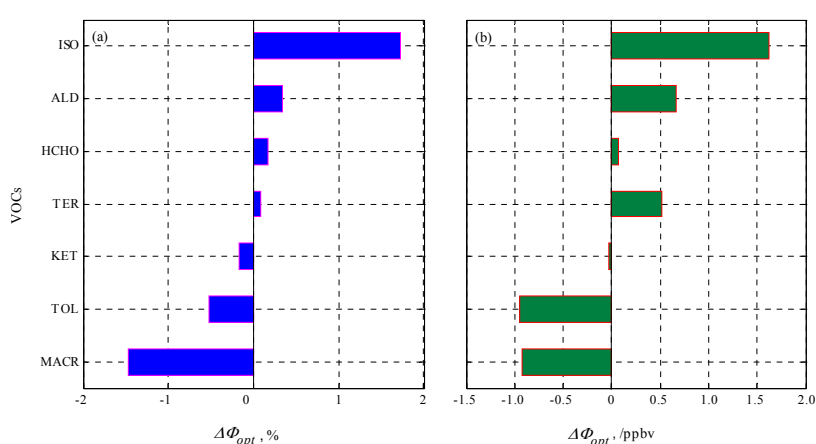

Fig. 6. Detailed comparison of the changes of $\Phi_{\text {opt }}\left(\Delta \Phi_{\text {opt }}\right)$ due to the increase of VOCs concentrations at 11:50 JST of 18 September. TER: monoterpenes.

radicals production. Thornton et al. (2002) also mentioned that the crossover between $\mathrm{NO}_{\mathrm{x}}$-limited and $\mathrm{NO}_{\mathrm{x}}$-saturated behaviour would shift to higher $\mathrm{NO}_{\mathrm{x}}$ levels, which implies a decrease of $\Phi_{\text {opt }}$ value when the production rate of radicals increases. Therefore, we use the model to test the robustness of our indicator to those factors which can improve the $\mathrm{OH}$ production rate, such as $\mathrm{O}_{3}$ concentration, humidity, $j\left(\mathrm{O}^{1} \mathrm{D}\right)$ etc.

Figure 7 shows the dependence of $P\left(\mathrm{O}_{3}\right)$ on $\Phi$ with different fixed $\mathrm{O}_{3}$ concentration under high and low $j\left(\mathrm{O}^{1} \mathrm{D}\right)$ conditions. As shown in Fig. 7a, the variations of $P\left(\mathrm{O}_{3}\right)$ have the same tendency with increasing $\Phi$ at each fixed concentration of $\mathrm{O}_{3} . P\left(\mathrm{O}_{3}\right)$ increases with increasing $\Phi$ at $\Phi<\Phi_{\text {opt }}$ and then reaches the maximum value at $\Phi_{\text {opt }}$. At $\Phi>\Phi_{\text {opt }}$, the further increase of $\Phi$ leads to a decrease of $P\left(\mathrm{O}_{3}\right)$. When the concentration of $\mathrm{O}_{3}$ is constrained to $1 \mathrm{ppbv}$, the value of $\Phi_{\text {opt }}$ is $\sim 9$. $\Phi_{\text {opt }}$ decreases to a value of 5 when $\mathrm{O}_{3}$ concentration rises to $100 \mathrm{ppbv}$. It reveals a negative correlation between ozone concentrations and $\Phi_{\text {opt }}$. Besides, the results from similar calculations under a low $j\left(\mathrm{O}^{1} \mathrm{D}\right)$ condition (Fig. 7b) are in qualitative agreement with those under a high $j\left(\mathrm{O}^{1} \mathrm{D}\right)$ condition. More importantly, it is found that the value of $\Phi_{\mathrm{opt}}$ under the condition of $1 \mathrm{ppbv} \mathrm{O}_{3}$ and high $j\left(\mathrm{O}^{1} \mathrm{D}\right)$ is nearly equal to it under the conditions of $100 \mathrm{ppbv}$ $\mathrm{O}_{3}$ and low $j\left(\mathrm{O}^{1} \mathrm{D}\right)$, which associates with the similar levels of $\mathrm{OH}$ radical, implying that the inherent factor of $\Phi_{\mathrm{opt}}$ is a radical production rate rather than ozone concentration or photolysis rate. Figure 8 shows the dependence of $P\left(\mathrm{O}_{3}\right)$ on $\Phi$ when the relative humidity (RH) is constrained to $10 \%$, $20 \%, 50 \%$ and $90 \%$, respectively. Under a high $j\left(\mathrm{O}^{1} \mathrm{D}\right)$ condition, as presented in Fig. 8a, the increase of $\mathrm{RH}$ associates with $\mathrm{OH}$ increase leading to a low $\Phi_{\text {opt }}$. However, increasing $\mathrm{RH}$ under a low $j\left(\mathrm{O}^{1} \mathrm{D}\right)$ condition can not bring significant change in radical production and, thus, leads to a nearly constant $\Phi_{\text {opt }}$ (as shown in Fig. 8b). Results from Fig. 7 and Fig. 8 provide reliable evidence of the value of $\Phi_{\text {opt }}$ anticorrelates with the radical production rate.
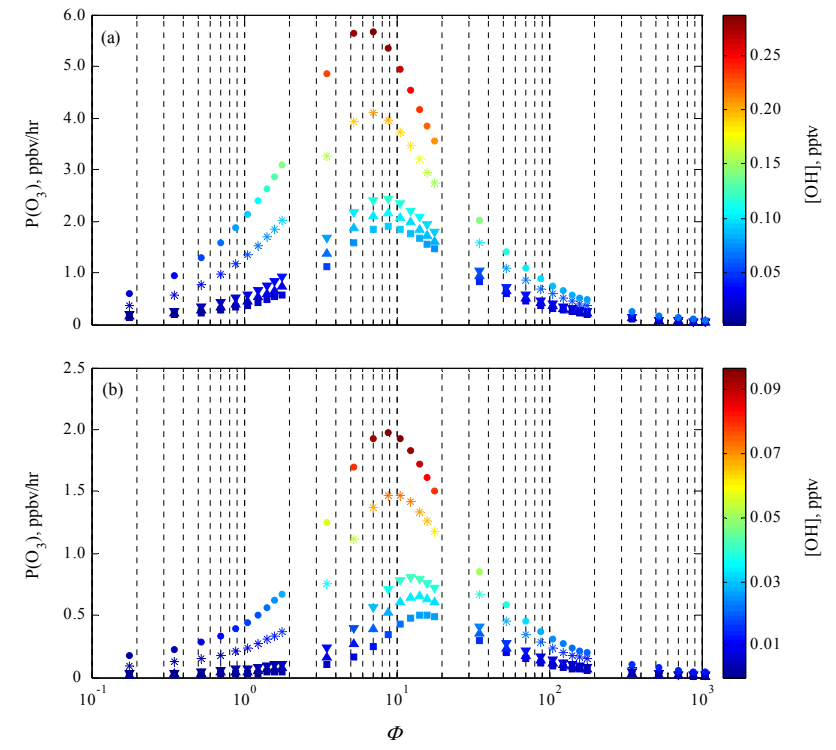

Fig. 7. Dependence of $P\left(\mathrm{O}_{3}\right)$ on $\Phi$ when the concentration of $\mathrm{O}_{3}$ is constrained to 1 ppbv (shown by square), 5 ppbv (shown by upward pointing triangle), $10 \mathrm{ppbv}$ (shown by downward pointing triangle), $50 \mathrm{ppbv}$ (shown by asterisk) and $100 \mathrm{ppbv}$ (shown by dot), respectively. The photolysis rates are constrained to those observed at (a) 11:50 JST and (b) 06:00 JST of 18 September. The $\mathrm{NO} / \mathrm{NO}_{2}$ ratio and other conditions are constrained to those observed at 11:50 JST of 18 September. The colour of the dots denotes the mixing ratio of $\mathrm{OH}$ radical.

From the definition of $\Phi$, we notice that the indicator value greatly relates to $\mathrm{NO} / \mathrm{NO}_{2}$ ratio when the sum concentration of $\mathrm{NO}_{\mathrm{x}}$ is fixed. Therefore, we also calculate $\Phi_{\mathrm{opt}}$ at different $\mathrm{NO} / \mathrm{NO}_{2}$ ratio, as shown in Fig. 9. The value of $\Phi_{\text {opt }}$ is about 6 at low $\mathrm{NO} / \mathrm{NO}_{2}$ ratio $\left(\mathrm{NO} / \mathrm{NO}_{2}=0.01\right)$, and the corresponding maximum $P\left(\mathrm{O}_{3}\right)\left(P\left(\mathrm{O}_{3}\right)_{\max }\right)$ is very low due to the high $\mathrm{NO}_{2}$ which can remove $\mathrm{OH}$ radical from the system. At high $\mathrm{NO} / \mathrm{NO}_{2}$ ratio $\left(\mathrm{NO} / \mathrm{NO}_{2}=100\right)$, the values of $\Phi_{\text {opt }}$ and $P\left(\mathrm{O}_{3}\right)_{\max }$ increase to 15 and $7.5 \mathrm{ppbv} / \mathrm{hr}$, respectively. As represented in Fig. 9, it is clear that the decrease of $\mathrm{NO} / \mathrm{NO}_{2}$ ratio leads to $\Phi_{\text {opt }}$ decrease, which can be well-explained by relevant chemistry of $\mathrm{NO}_{\mathrm{x}}$. In the fast photochemical cycling of $\mathrm{NO}_{\mathrm{x}}$ in daytime, the $\mathrm{NO} / \mathrm{NO}_{2}$ ratio is determined by the concentrations of $\mathrm{O}_{3}$ and peroxy radicals as well as $j\left(\mathrm{NO}_{2}\right)$ (Cadle et al., 1952; Leighton et al., 1961; Crawford et al., 1996):

$\frac{[\mathrm{NO}]}{\left[\mathrm{NO}_{2}\right]}=\frac{j\left(\mathrm{NO}_{2}\right)}{\left(k_{1}\left[\mathrm{O}_{3}\right]+k_{2}\left[\mathrm{HO}_{2}\right]+k_{3}\left[\mathrm{RO}_{2}\right]\right)}$

where $k_{1}, k_{2}$ and $k_{3}$ are the rate constant of the reaction of $\mathrm{NO}$ with $\mathrm{O}_{3}, \mathrm{HO}_{2}$ and $\mathrm{RO}_{2}$, respectively. $j\left(\mathrm{NO}_{2}\right)$ is the photolysis rate of $\mathrm{NO}_{2}$. Equation (6) is proven to be suitable for remote locations (McFarland et al., 1978; Ritter et al., 1979; Fehsenfeld et al., 1983; Parrish et al., 1986; Trainer et al., 1987). Indubitably, an increase of $\mathrm{NO} / \mathrm{NO}_{2}$ ratio associates 

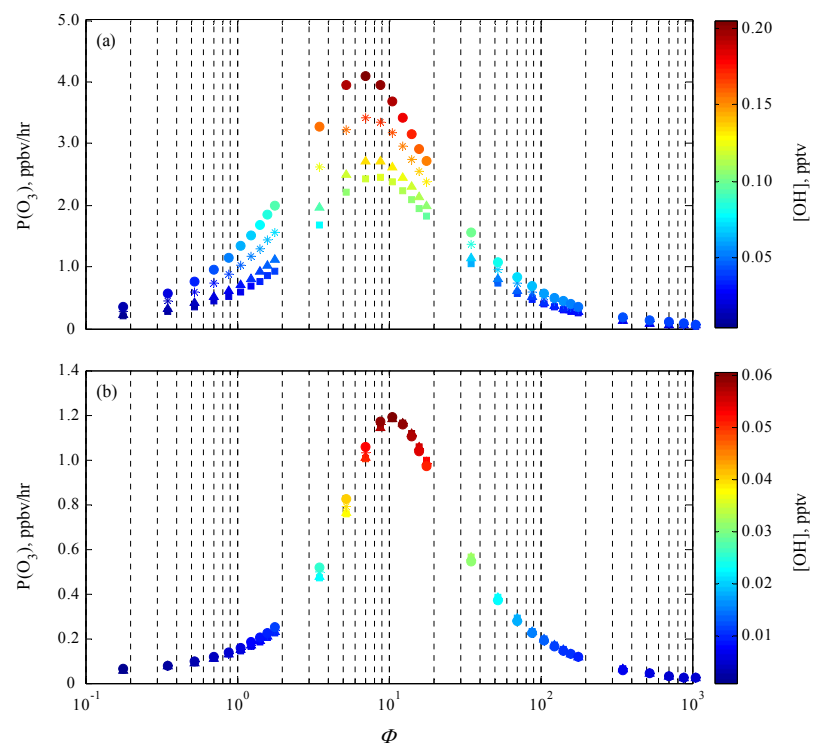

Fig. 8. Dependence of $P\left(\mathrm{O}_{3}\right)$ on $\Phi$ when the relative humidity is constrained to $10 \%$ (shown by square), $20 \%$ (shown by triangle), $50 \%$ (shown by asterisk) and $90 \%$ (shown by dot), respectively. The photolysis rates are constrained to those observed at (a) 11:50 JST and (b) 06:00 JST of 18 September. The $\mathrm{NO} / \mathrm{NO}_{2}$ ratio and other conditions are constrained to those observed at 11:50 JST of 18 September. The colour of the dots denotes the mixing ratio of $\mathrm{OH}$ radical.

with the decrease of peroxy radicals which indicates a lower $\Phi_{\text {opt }}$, in accordance with our model results.

As mentioned above, the value of $\Phi_{\text {opt }}$ is influenced by the local atmospheric composition of VOCs, ozone concentration, relative humidity, photolysis rate and $\mathrm{NO} / \mathrm{NO}_{2}$ ratio. However, $\Phi_{\text {opt }}$ varies within a range of $5 \sim 15$ in our case studies, indicating that $\Phi$ is robust against those parameters and can be used as an effective indicator to investigate the sensitivity of ozone production to $\mathrm{NO}_{\mathrm{x}}$ and $\mathrm{HC}$. In this paper, the variation of $\Phi$ values at the border between Regime III and IV is not discussed, for that a reduction of $\mathrm{NO}_{\mathrm{x}}$ is always useful to decrease ozone formation in this region.

\subsection{Behaviour of $P\left(\mathrm{O}_{3}\right)$ in different regimes}

The ozone production rate is estimated additionally using the peroxy radicals derived from the model using Eq. (2). Basically, the modelled $P\left(\mathrm{O}_{3}\right)\left(P\left(\mathrm{O}_{3}\right)_{\text {mod }}\right)$ track the diurnal and day-to-day variation of the observed $P\left(\mathrm{O}_{3}\right)\left(P\left(\mathrm{O}_{3}\right)_{\text {obs }}\right)$ well (Fig. 10). A detailed comparison between them is shown in Fig. 11. The $P\left(\mathrm{O}_{3}\right)_{\text {obs }} / P\left(\mathrm{O}_{3}\right)_{\text {mod }}$ ratio is clearly higher than one unit when $\Phi$ is lower than 10 (Regime II) under high $j\left(\mathrm{O}^{1} \mathrm{D}\right)$ condition $\left(j\left(\mathrm{O}^{1} \mathrm{D}\right)>10^{-6}\right)$, where the corresponding values of $d \ln P\left(\mathrm{O}_{3}\right) / d \ln [\mathrm{HC}]$ are commonly higher than 0.8 . It implies that the model tends to underestimate $P\left(\mathrm{O}_{3}\right)$ when $P\left(\mathrm{O}_{3}\right)$ is greatly sensitive to $\mathrm{HC}$, which indicates that an important source of peroxy radicals may be missed, as men-

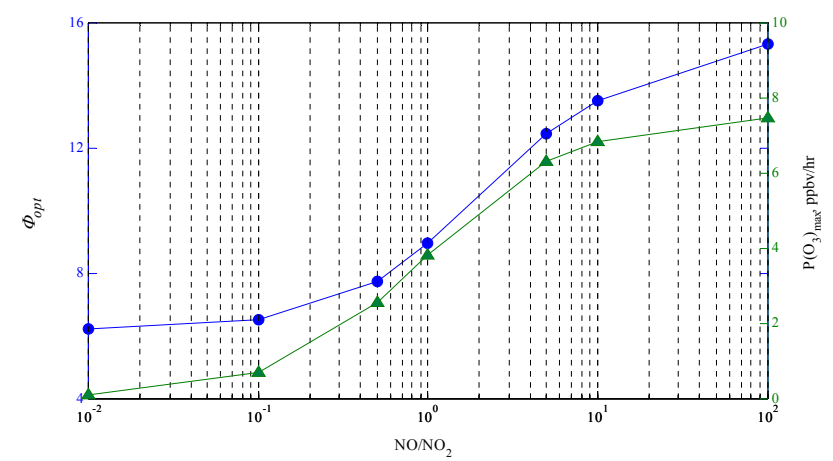

Fig. 9. Dependence of $\Phi_{\text {opt }}$ (blue circle) and $P\left(\mathrm{O}_{3}\right)_{\max }$ (green triangle) on different $\mathrm{NO} / \mathrm{NO}_{2}$ ratio.

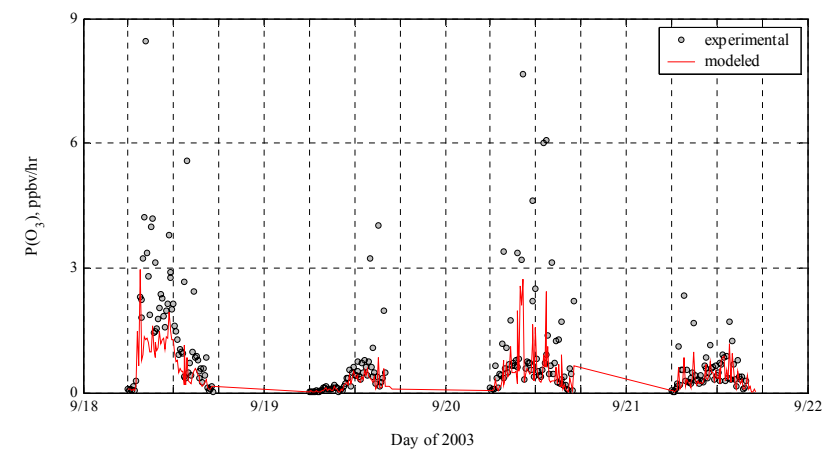

Fig. 10. Time series of experimental and modelled $P\left(\mathrm{O}_{3}\right)$ in 10-min averages during 18-21 September 2003.

tioned by Qi et al. (2007). This behaviour reveals that the observed $P\left(\mathrm{O}_{3}\right)$ as well as peroxy radicals used to estimate the value of $P\left(\mathrm{O}_{3}\right)$ are significantly higher than the model results under high $\mathrm{NO}_{\mathrm{x}}$ conditions, which is consistent with several previous studies in different environments (Tan et al., 2001; Martinez et al., 2003; Ren et al., 2005). On the contrary, the underestimated trend becomes weaker with increasing $\Phi$ in Regime IV where $P\left(\mathrm{O}_{3}\right)$ is insensitive to HC. In this region, the value of $P\left(\mathrm{O}_{3}\right)_{\text {obs }} / P\left(\mathrm{O}_{3}\right)_{\text {mod }}$ is commonly lower than one unit under a low $j\left(\mathrm{O}^{1} \mathrm{D}\right)$ condition $\left(j\left(\mathrm{O}^{1} \mathrm{D}\right)<10^{-6}\right)$, implying that our model may overestimate the production of peroxy radicals which is not formed by photochemistry.

Figure 12 shows the calculated itemization of $P\left(\mathrm{O}_{3}\right)$ in different regimes. The average $P\left(\mathrm{O}_{3}\right)$ is $3.22 \mathrm{ppbv} / \mathrm{hr}$ in Regime II, $2.07 \mathrm{ppbv} / \mathrm{hr}$ in Regime III and $0.78 \mathrm{ppbv} / \mathrm{hr}$ in Regime IV, respectively, which illuminates a decrease of $P\left(\mathrm{O}_{3}\right)$ with increasing $\Phi$. In all regimes, $P\left(\mathrm{O}_{3}\right)$ is dominated by $\mathrm{HO}_{2}+\mathrm{NO}$ reaction and followed by $\mathrm{MO}_{2}+\mathrm{NO}$ reaction. These two reactions contribute ca. $69 \%$ and $16 \%$ in Regime II, $67 \%$ and $17 \%$ in Regime III, $66 \%$ and $19 \%$ in Regime IV, respectively. Reactions of other peroxy radicals with $\mathrm{NO}$ contribute very little. As $\Phi$ increases, the contribution ratio of $\mathrm{HO}_{2}+\mathrm{NO}$ reaction to the sum of $\mathrm{RO}_{2}+\mathrm{NO}$ 

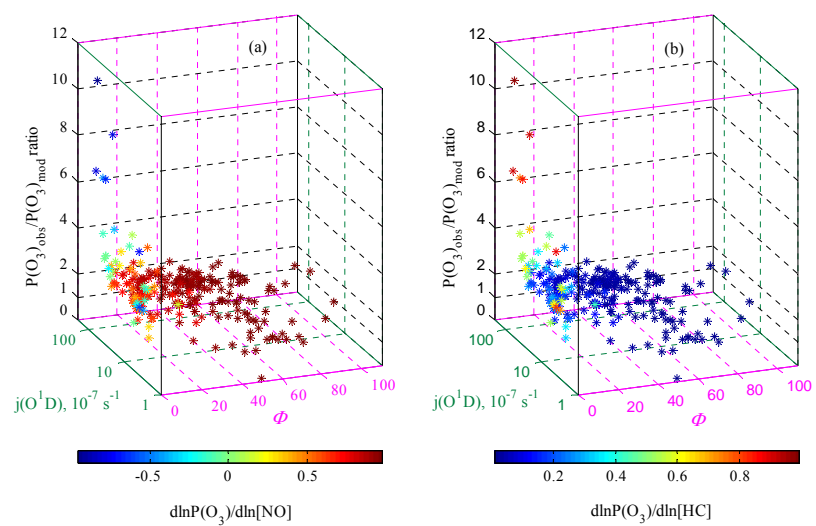

Fig. 11. Dependence of the ratio of observed $P\left(\mathrm{O}_{3}\right)$ to modelled $P\left(\mathrm{O}_{3}\right)\left(P\left(\mathrm{O}_{3}\right)_{\mathrm{obs}} / P\left(\mathrm{O}_{3}\right)_{\bmod }\right)$ on (a) $d \ln P\left(\mathrm{O}_{3}\right) / d \ln [\mathrm{NO}]$ and (b) $d \ln P\left(\mathrm{O}_{3}\right) / d \ln [\mathrm{HC}]$ at different $j\left(\mathrm{O}^{1} \mathrm{D}\right)$ and $\Phi$ values for daytime 10-min average data during 18-21 September 2003. The colour of the asterisks shows (a) $d \ln P\left(\mathrm{O}_{3}\right) / d \ln [\mathrm{NO}]$ and (b) $d \ln P\left(\mathrm{O}_{3}\right) / d \ln [\mathrm{HC}]$ at the corresponding time.

reactions decreases, this indicates a decrease of the efficiency of the $\mathrm{RO}_{2}$ to $\mathrm{HO}_{2}$ conversion via the reaction of $\mathrm{RO}_{2}$ with NO. The percent contributions of all $\mathrm{RO}_{2}+\mathrm{NO}$ reactions show an increasing trend when $\Phi$ shifts from Regime II to IV, except for an abnormally high contribution of TERP+NO in Regime II and ISOP+NO in Regime III, leading by the high $\mathrm{OH}$ reactivity towards monoterpenes ( $L$ (TER)) and isoprene $(L(\mathrm{ISO}))$ in the corresponding regimes. The values of $L$ (TER), NO concentration and the average $P\left(\mathrm{O}_{3}\right)$ formed by monoterpenes $+\mathrm{NO}$ reactions in Regime II are higher than these in Regime IV by a factor of 1.16, 14.25 and 5.76, implying the effect of $\mathrm{NO}$ on $P\left(\mathrm{O}_{3}\right)$ is weaker in Regime II than in Regime IV. For isoprene, the corresponding values of $L$ (ISO), NO and the average $P\left(\mathrm{O}_{3}\right)$ in Regime III are higher than those in Regime IV by a factor of 1.36, 3.45 and 2.93, revealing that the effect of $\mathrm{NO}$ on $P\left(\mathrm{O}_{3}\right)$ in Regime III is weaker than in Regime IV. The discussion above reveals that the ozone production rate is more sensitive to $\mathrm{NO}$ in Regime IV than in Regime II and III.

As Fig. 12 shows, the 10-min average data of $P\left(\mathrm{O}_{3}\right)$ are categorized into three classes by $j\left(\mathrm{O}^{1} \mathrm{D}\right)$ $\left(\mathrm{s}^{-1}\right)$ value: (1) $j\left(\mathrm{O}^{1} \mathrm{D}\right)<10^{-6} \mathrm{~s}^{-1}$ (denoted as $\mathrm{J} 1$ ), (2) $10^{-5} \mathrm{~s}^{-1}>j\left(\mathrm{O}^{1} \mathrm{D}\right)>10^{-6} \mathrm{~s}^{-1}$ (denoted as $\mathrm{J} 2$ ) and (3) $j\left(\mathrm{O}^{1} \mathrm{D}\right)>10^{-5} \mathrm{~s}^{-1}$ (denoted as $\mathrm{J} 3$ ) in each regimes. In Regime II, the average value of $P\left(\mathrm{O}_{3}\right)$ is $0.28 \mathrm{ppbv} / \mathrm{hr}$ at $\mathrm{J} 1,0.74 \mathrm{ppbv} / \mathrm{hr}$ at $\mathrm{J} 2$ and $2.20 \mathrm{ppbv} / \mathrm{hr}$ at $\mathrm{J} 3$, respectively. As $j\left(\mathrm{O}^{1} \mathrm{D}\right)$ increases, $P\left(\mathrm{O}_{3}\right)$ in Regime II increases greatly, which is possibly because of the increasing concentration of peroxy radicals. This indicates that the concentration of peroxy radicals is an important factor in controlling ozone production in Regime II, thus, $P\left(\mathrm{O}_{3}\right)$ is sensitive to $L(\mathrm{HC})$ as well as HC. In Regime III and Regime IV, the average value of $P\left(\mathrm{O}_{3}\right)$ is 0.21 and $0.06 \mathrm{ppbv} / \mathrm{hr}$ at $\mathrm{J} 1$ level, 0.53 and

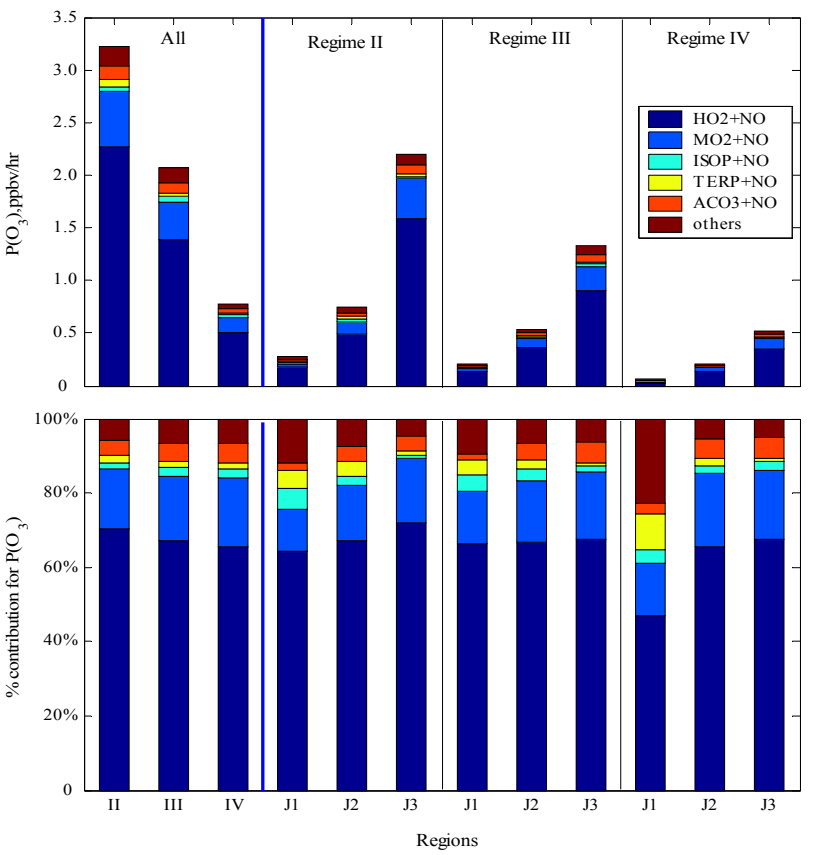

Fig. 12. Itemization of $P\left(\mathrm{O}_{3}\right)$ calculated in different regimes. The 10-min average data of $P\left(\mathrm{O}_{3}\right)$ are categorized into three classes by $j\left(\mathrm{O}^{1} \mathrm{D}\right)\left(\mathrm{s}^{-1}\right)$ values: (J1) $j\left(\mathrm{O}^{1} \mathrm{D}\right)<10^{-6} \mathrm{~s}^{-1}$, (J2) $10^{-5} \mathrm{~s}^{-1}>$ $j\left(\mathrm{O}^{1} \mathrm{D}\right)>10^{-6} \mathrm{~s}^{-1}$ and $(\mathrm{J} 3) j\left(\mathrm{O}^{1} \mathrm{D}\right)>10^{-5} \mathrm{~s}^{-1}$. TERP: peroxy radicals from monoterpenes.

$0.20 \mathrm{ppbv} / \mathrm{hr}$ at $\mathrm{J} 2$ level and 1.33 and $0.51 \mathrm{ppbv} / \mathrm{hr}$ at $\mathrm{J} 3$ level, respectively. In these two regimes, the increase of $P\left(\mathrm{O}_{3}\right)$ (especially in Regime IV) caused by increasing $j\left(\mathrm{O}^{1} \mathrm{D}\right)$ is clearly less than in Regime II. The effect of peroxy radicals to control $\mathrm{O}_{3}$ production becomes weaker with increasing $\Phi$, which implies a declining sensitivity of $P\left(\mathrm{O}_{3}\right)$ to $\mathrm{HC}$. In the condition of $\mathrm{J} 1$ in Regime IV, the percentage contribution of monoterpenes $+\mathrm{NO}$ reactions to $P\left(\mathrm{O}_{3}\right)$ is clearly higher than in other conditions, which possibly associates with the elevated monoterpenes in this region. In such a case, the monoterpenes $+\mathrm{O}_{3}$ reactions may be significant for the production of peroxy radicals. As these peroxy radicals cannot efficiently convert to $\mathrm{HO}_{2}$ radical under low $\mathrm{NO}_{\mathrm{x}}$ condition, it leads to a low percentage contribution of $\mathrm{HO}_{2}+\mathrm{NO}$ reaction to ozone production (as shown in Fig. 12). Meanwhile, a low $P\left(\mathrm{O}_{3}\right)_{\text {obs }} / P\left(\mathrm{O}_{3}\right)_{\text {mod }}$ ratio found in this region (Fig. 11) implies that the reactions of monoterpenes with ozone may over-predict the yield of peroxy radicals.

The island is located in the sea of Japan and is more free from impact of human activities. However, the plants are abundant over the island, thus, the emission of BVOCs such as isoprene and monoterpenes can be significant (Tanimoto et al., 2000; Kanaya et al., 2002a, 2002b). In order to find the controlling factor for ozone production, it is necessary to analyse $P\left(\mathrm{O}_{3}\right)$ sensitivity to BVOCs and $\mathrm{NO}_{\mathrm{x}}$. Firstly, sensitivity runs for $P\left(\mathrm{O}_{3}\right)$ are performed by changing $\mathrm{NO}_{\mathrm{x}}$ and monoterpenes concentrations. In the calculations, ozone 

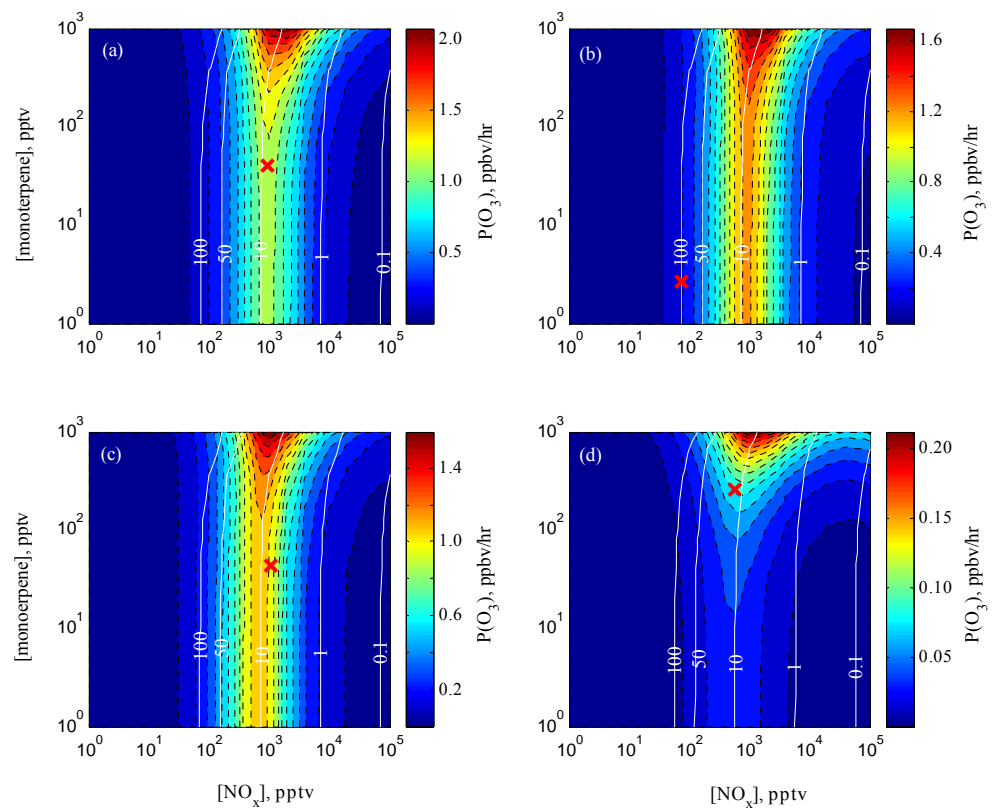

Fig. 13. Calculated dependence of $P\left(\mathrm{O}_{3}\right)$ upon monoterpenes concentrations and $\mathrm{NO}_{\mathrm{x}}$ concentrations. Other conditions including $j\left(\mathrm{O}^{1} \mathrm{D}\right)$ are constrained to those observed at: (a) 08:40 JST of 18 September, (b) 13:10 JST of 21 September, (c) 13:00 JST of 20 September and (d) 06:40 JST of 21 September. The contour plots of $\Phi$ are shown by whiter lines. Red crosses denote the observed concentrations of monoterpenes and $\mathrm{NO}_{\mathrm{x}}$ at the selected time.

and its precursors except for $\mathrm{NO}_{\mathrm{x}}$ and monoterpenes are basically constrained to those observed at four selected times in our observation. Each run is performed with the sum mixing ratio of $\mathrm{NO}_{\mathrm{x}}$ fixed at a value between $1 \mathrm{pptv}$ to $100 \mathrm{ppbv}$, and the $\mathrm{NO} / \mathrm{NO}_{2}$ ratio is constrained to be observed at the selected time. Monoterpenes concentration is fixed at a value between $1 \mathrm{pptv}$ to $1 \mathrm{ppbv}$, covering the concentration range observed during our campaign. The model results are shown in Fig. 13.

As Fig. 13a shows, the system is situated on the border between Regime II and Regime III, thus, a ridge $P\left(\mathrm{O}_{3}\right)$ appears and the current ozone production is sensitive to monoterpenes change but not sensitive to $\mathrm{NO}_{\mathrm{x}}$. In Fig. 13b, the labelled area is in Regime IV which indicates that $P\left(\mathrm{O}_{3}\right)$ is controlled by $\mathrm{NO}_{\mathrm{x}}$, therefore, $P\left(\mathrm{O}_{3}\right)$ is sensitive to $\mathrm{NO}_{\mathrm{x}}$ but nearly insensitive to monoterpenes. As shown in Fig. 13c, the labelled $P\left(\mathrm{O}_{3}\right)$ is in Regime II and shows a negative sensitivity to $\mathrm{NO}_{\mathrm{x}}$ but a positive one to monoterpenes which agrees well with the character of $P\left(\mathrm{O}_{3}\right)$ sensitivity in this region. In addition, Fig. $13 \mathrm{~d}$ shows a case labelled $P\left(\mathrm{O}_{3}\right)$ that appears in Regime III. It is clear that $P\left(\mathrm{O}_{3}\right)$ in the selected area is sensitive to both monoterpenes and $\mathrm{NO}_{\mathrm{x}}$ changes, which is in good agreement with the results represented by the indicator. We also test the $P\left(\mathrm{O}_{3}\right)$ sensitivity to $\mathrm{NO}_{\mathrm{x}}$ and isoprene and obtain a similar result. In summary, sensitivity studies clearly reveal the $P\left(\mathrm{O}_{3}\right)$ sensitivity to $\mathrm{NO}_{\mathrm{x}}$ and $\mathrm{HC}$ in four regimes, in accordance with the results derived from the indicator.

\section{Conclusions}

In this work, we use an indicator $\Phi=k_{\mathrm{HC}+\mathrm{OH}}[\mathrm{HC}] /$ $k_{\mathrm{NO}_{\mathrm{x}}+\mathrm{OH}}\left[\mathrm{NO}_{\mathrm{x}}\right]$ to investigate the $P\left(\mathrm{O}_{3}\right)$ sensitivity to $\mathrm{HC}$ and $\mathrm{NO}_{\mathrm{x}}$ in the field campaign RISFEX 2003 made in September 2003 at Rishiri Island in the sea of Japan. Four different sensitivity regimes are obtained based on the indicator. Specifically, $P\left(\mathrm{O}_{3}\right)$ almost linearly increases with increasing $\mathrm{HC}$ and almost linearly decreases with increasing $\mathrm{NO}_{\mathrm{x}}$ in Regime I $(\Phi<1)$. In Regime II $(1<\Phi<9 \pm 5)$, there is a less-than-linear increase in $P\left(\mathrm{O}_{3}\right)$ with $\mathrm{HC}$ and a less-than-linear decrease with $\mathrm{NO}_{\mathrm{x}} \cdot \quad P\left(\mathrm{O}_{3}\right)$ less-thanlinearly increases with both $\mathrm{HC}$ and $\mathrm{NO}_{\mathrm{x}}$ in Regime III $(9 \pm 5<\Phi<45 \pm 7)$, and near linearly increases with $\mathrm{NO}_{\mathrm{x}}$ and is nearly constant with increasing $\mathrm{HC}$ in Regime IV $(\Phi>45 \pm 7)$. During the four daytimes, there are 24, 127 and 120 data points located in Regime II, III and IV, respectively. It implies that approximately $91 \%$ of $P\left(\mathrm{O}_{3}\right)$ data appear in $\mathrm{NO}_{\mathrm{x}}$ positive sensitive region, illuminating that $\mathrm{NO}_{\mathrm{x}}$ is a limiting factor for ozone production, thus, a controlling of $\mathrm{NO}_{\mathrm{x}}$ emission can be a more efficient strategy for ozone abatement on the island.

The observed $P\left(\mathrm{O}_{3}\right)$ are compared with those derived from the model and give the results generally in an agreement. However, the model tends to underestimate $P\left(\mathrm{O}_{3}\right)$ when $P\left(\mathrm{O}_{3}\right)$ is greatly sensitive to $\mathrm{HC}$ in Regime II, but this underestimated trend becomes weaker in Regime III and nearly disappears in Regime IV. It reveals that an important source of peroxy radicals may be missed. In Regime IV, 
the low $P\left(\mathrm{O}_{3}\right)_{\text {obs }} / P\left(\mathrm{O}_{3}\right)_{\text {mod }}$ values under the conditions with low $j\left(\mathrm{O}^{1} \mathrm{D}\right)$ and elevated monoterpenes indicate that our current model may over-predict the formation of peroxy radicals from the reactions of monoterpenes with ozone. Budget analysis shows that $P\left(\mathrm{O}_{3}\right)$ is dominated by the $\mathrm{HO}_{2}+\mathrm{NO}$ reaction and followed by the $\mathrm{MO}_{2}+\mathrm{NO}$ reaction in all regimes. The two reactions contribute ca. $69 \%$ and $16 \%$ in Regime II, $67 \%$ and $17 \%$ in Regime III, $66 \%$ and $19 \%$ in Regime IV, respectively. Reactions of other peroxy radicals with $\mathrm{NO}$ contribute very little. Meanwhile, the ratio of the percentage contribution of the $\mathrm{HO}_{2}+\mathrm{NO}$ reaction to $\mathrm{RO}_{2}+\mathrm{NO}$ reactions decreases as $\Phi$ increases, indicating a decrease efficiency of the $\mathrm{RO}_{2}$ to $\mathrm{HO}_{2}$ conversion via the reaction of $\mathrm{RO}_{2}$ with NO. Moreover, it shows a declining sensitivity of $P\left(\mathrm{O}_{3}\right)$ to $\mathrm{HC}$ but a ascending sensitivity of $P\left(\mathrm{O}_{3}\right)$ to $\mathrm{NO}_{\mathrm{x}}$ when the situation shifts from Regime II to Regime IV, which is consistent with the variation of $P\left(\mathrm{O}_{3}\right)$ sensitivity with increasing $\Phi$. Sensitivity analysis indicates the sensitivity of $P\left(\mathrm{O}_{3}\right)$ to $\mathrm{NO}_{\mathrm{x}} /$ monoterpenes changes in different regimes, which shows a good agreement with the results from the indicator. Those studies approve the indicator is successful in ascertaining the character of $P\left(\mathrm{O}_{3}\right)$ sensitivity at the site.

Edited by: N. Riemer

\section{References}

Alicke, B., Geyer, A., Hofzumahaus, A., Holland, F., Konard, S., Pätz, H. W., Schäfer, J., Stutz, J., Andreas, V. T., and Platt, U.: OH formation by HONO photolysis during the BERLIOZ experiment, J. Geophys. Res., 108(D4), 8247, doi:1029/2001JD000579, 2003.

Ariya, P. A., Sander, R., and Crutzen, P. J.: Significance of $\mathrm{HO}_{\mathrm{x}}$ and peroxides production due to alkene ozonolysis during fall and winter: A modeling study, J. Geophys. Res., 105, 1772117739, 2000.

Bojkov, R. D.: Ozone changes at the surface and in the free troposphere, in: Tropospheric Ozone, edited by: Isaksen, I. S. A., Reidel, Dordrecht, 83-96, 1988.

Brasseur, G. J., Kiehl, T., Muller, J. F., Schneider, T., Granier, C., Tie, X. X., and Hauglustaine, D.: Past and future changes in global tropospheric ozone: Impact on radiative forcing, Geophys. Res. Lett., 25, 3807-3810, 1998.

Burkert, J., Andres, M. D., Stobener, D., Burrows, J. P., Weissenmayer, M., and Kraus, A.: Peroxy radical and related trace gas measurements in the boundary layer above the Atlantic Ocean, J. Geophys. Res., 106, 5457-5477, 2001.

Cadle, R. D. and Johnston, H. S.: Chemical reaction in Los Angeles smog, Proc. Natl, Air Pollution Symp., 2nd, 1952.

Cantrell, C. A. and Stedman, D. H.: A possible technique for the measurement of atmospheric peroxy radicals, Geophys. Res. Lett., 9, 846-849, 1982.

Carpenter, L. J., Monks, P. S., Galbally, I. E., Meyer, C. P., Bandy, B. J., and Penkett, S. A.: A study of peroxy radicals and ozone photochemistry at coastal sites in the Northern and Southern Hemisphere, J. Geophys. Res., 102, 25417-25427, 1997.

Chameides, W. and Walker, J. C. G.: A photochemical theory of tropospheric ozone, J. Geophys. Res., 78, 8751-8760, 1973.

Crawford, J. and Davis, D.: Photostationary state analysis of the $\mathrm{NO}-\mathrm{NO}_{2}$ system based on airborne observations from the western and central North Pacific, J. Geophys. Res., 101, 2053-2072, 1996.

Fehsenfeld, F. C., Bollinger, M. J., Liu, S.C., Parrish, D. D., McFarland, M., Trainer, M., Kley, D., Murphy, P. C., Albritton, D. L., and Lenschow, D. H.: A study of ozone in the Colorado mountains, J. Atmos. Chem., 1, 87-105, 1983.

Fishman, J. and Crutzen, P. J.: A numerical study of tropospheric photochemistry using a one-dimensional model, J. Geophys. Res., 82, 5897-5906, 1977.

Fishman, J. and Crutzen, P. J.: The origin of ozone in the troposphere, Nature, 274, 855-858, 1978.

Fleming, Z. L., Monks, P. S., Rickard, A. R., Heard, D. E., Bloss, W. J., Seakins, P. W., Still, T. J., Sommariva, R., Pilling, M. J., Morgan, R., Green, T. J., Brough, N., Mills, G. P., Penkett, S. A., Lewis, A. C., Lee, J. D., Saiz-Lopez, A., and Plane, J. M. C.: Peroxy radical chemistry and the control of ozone photochemistry at Mace Head, Ireland during the summer of 2002, Atmos. Chem. Phys., 6, 2193-2214, doi:10.5194/acp-6-2193-2006, 2006.

Frank, K., Francois, J., Alain, C., Bernd, K., Hubert, B., and Bertrand C.: Total VOC reactivity in the planetary boundary layer: 2. A new indicator for determining the sensitivity of the ozone production to VOC and $\mathrm{NO}_{\mathrm{x}}$, J. Geophy. Res., 106, 30953110, 2001.

Geyer, A., Bächmann, K., Hofzumahaus, A., Holland, F., Konrad S., Klüpfel, T., Pätz, H. W., Perner, D., Mihelcic, D., Schäfer, H. J., Andreas, V. T., and Platt, U.: Nighttime formation of peroxy and hydroxyl radicals during the BERLIOZ campaign: Observations and modeling studies, J. Geophy. Res., 108(D4), 8249, doi:10.1029/2001JD000656, 2003.

Hein, R., Crutzen, P. J., and Heimann, M.: An inverse modeling approach to investigate the global atmospheric methane cycle, Global Biogeochem. Cy., 11, 43-76, 1997.

Holland, F., Aschumutat, U., Hebling, M., Hofzumahaus, A., and Ehhalt, D. H.: Highly time resolved measurements of $\mathrm{OH}$ during POPCORN using laser-induced fluorescence spectroscopy, J. Atmos. Chem., 31, 205-225, 1998.

Holland, F., Hofzumahaus, A., Schäfer, J., Kraus, A., and Pätz, H. W.: Measurements of $\mathrm{OH}$ and $\mathrm{HO}_{2}$ radical concentrations and photolysis frequencies during BERLIOZ, J. Geophy. Res., 108(D4), 8246, doi:10.1029/2001JD001393, 2003.

Kanaya, Y., Nakamura, K., Kato, S., Matsumoto, J., Tanimoto, H., and Akimoto, $\mathrm{H}$.: Nighttime variations in $\mathrm{HO}_{2}$ radical mixing ratios at Rishiri Island observed with elevated monoterpene mixing ratios, Atmos. Environ., 36, 4929-4940, 2002a.

Kanaya, Y., Yokouchi, Y., Matsumoto, J., Nakamura, K., Kato, S., Tanimoto, H., Furutani, H., Toyota, K., and Akimoto, H.: Implications of iodine chemistry for daytime HO2 levels at Rishiri Island, Geophys. Res. Lett., 29(8), 1212, doi:10.1029/2001GL014061, 2002b.

Kanaya, Y., Matsumoto, J., and Akimoto, H.: Photochemical ozone production at a subtropical island of Okinawa, Japan: Impactions from simultaneous observations of $\mathrm{HO}_{2}$ radical and $\mathrm{NO}_{\mathrm{x}}$, J. Geophys. Res., 107(D19), 4368, doi:10.1029/2001JD000858, 2002c. 
Kleinman, L. I.: Photochemical formation of peroxides in the boundary layer, J. Geophys. Res., 91, 10889-10904, 1986.

Kleinman, L. I.: Seasonal dependence of boundary layer peroxide concentration: The low- and high- $\mathrm{NO}_{\mathrm{x}}$ regimes, J. Geophys. Res., 96, 20721-20734, 1991.

Kleinman, L. I., Lee, Y. N., Springston, S. R., Lee, J. H., Nunnermacker, L. J., Weinstein, J. L., Zhou, X., and Newman, L.: Peroxy radical concentration and ozone formation rate at a rural site in southeastern United States, J. Geophys. Res., 100, 7263-7273, 1995.

Kleinman, L. I., Daum, P. H., Lee, J. H., Lee, Y. N., Nunnermacker, L. J., Springston, S. R., Newman, L., Judith, W. L., and Sanford S.: Dependence of ozone production on NO and hydrocarbons in the troposphere, Geophys. Res. Lett., 24, 2299-2302, 1997.

Kleinman, L. I., Daum, P. H., Lee, Y.-N., Nunnermacker, L. J., Springston, S. R., Weinstein-Lloyd, J., and Rudolph, J.: A comparative study of ozone production in five U.S. metropolitan areas, J. Geophys. Res., 110, D02301, doi:10.1029/2004JD005096, 2005.

Leighton, P. A.: Photochemistry of Air Pollution, Academic, San Diego, Calif., 1961.

Liu, S. C., Kley, D., McFarland, M., Mahlman, J. D., and Levy II, H.: On the origin of tropospheric ozone, J. Geophys. Res., 85, 7546-7552, 1980.

Liu, S. C., Trainer, M., Fehsenfeld, F. C., Parrish, D. D., Williams, E. J., Fahey, D. W., Hubler, G., and Murphy, P. C.: Ozone production in the rural troposphere and the implications for regional and global ozone distributions, J. Geophys. Res., 92, 4194-4207, 1987.

Logan, J. A.: Tropospheric ozone: seasonal behaviour, trends and anthropogenic influence, J. Geophys. Res., 90, 10463-10482, 1985.

Logan, J. A.: An analysis of ozonesonde data for the troposphere: Recommendations for testing 3-D models and development of a gridded climatology for tropospheric ozone, J. Geophys. Res., 104(D13), 16115-16149, 1999.

Martinez, M., Harder, H., Kovacs, T. A., Simpas, J. B., Bassis, J., Lesher, R., Brune, W. H., Frost, G., Williams, E. J., Stroud, C. A., Jobson, B. T., Roberts, J. M., Hall, S. R., Shetter, R. E., Wert, B., Fried, A., Alicke, B., Stutz, J., Young, V. L., White, A. B., and Zamora, R. J.: $\mathrm{OH}$ and $\mathrm{HO}_{2}$ concentrations, sources and loss rates during the Southern Oxidants Study in Nashville, TN, summer 1999, J. Geophys. Res., 108, 4617, doi:10.1029/2003JD003551, 2003.

McFarland, M., Kley, D., and Drummond, J. W.: Simultaneous NO, $\mathrm{NO}_{2}$, and $\mathrm{O}_{3}$ vertical profile measurements from ground level to $6 \mathrm{~km}$, paper presented at the 4th Biennial Rocky Mountain Regional Meeting, Am. Chem. Soc., Boulder, Colo., June 1978.

Mihelcic, D., Holland, F., Hofzumahaus, A., Hoppe, L., Konrad, S., Musgen, P., Patz, H. W., Schafer, H. J., Schmitz, T., VolzThomas, A., Bachmann, K., Schlomski, S., Platt, U., Geyer, A., Alicke, B., and Moortgat, G. K.: Peroxy radicals during BERLIOZ at Pabstthum: Measurements, radical budgets and ozone production, J. Geophys. Res., 108, 8254-8268, 2003.

Milford, J., Gao, D., Sillman, S., Blossey, P., and Russell, A. G.: Total reactive nitrogen $\left(\mathrm{NO}_{\mathrm{y}}\right)$ as an indicator for the sensitivity of ozone to $\mathrm{NO}_{\mathrm{x}}$ and hydrocarbons, J. Geophys. Res., 99, 35333542, 1994.

Monks, P. S., Carpenter, L. J., Penkett, S. A., Ayers, G. P., Gillett,
R. W., Galbally, I. E., and Meyer, C. P.: Fundamental ozone photochemistry in the remote boundary layer: The SOAPEX experiment, measurement and theory, Atmos. Environ., 32, 3647-3664, 1998.

Monks, P. S.: A review of the observations and origins of the spring ozone maximum, Atmos. Environ., 34, 3545-3561, 2000.

Paulson, S. E. and Orlando, J. J.: The reactions of ozone with alkenes: An important source of $\mathrm{HO}_{\mathrm{x}}$ in the boundary layer, Geophys. Res. Lett., 23, 3727-3730, 1996.

Parrish, D. D., Trainer, M., Williams, E . J., Fahey, D. W., Hubler, G., Eubank, C. S., Liu, S. C., Murphy, P. C., Albritton, D. L., and Fehsenfeld, F.: Measurements of the NO-O 3 photostationary state at Niwot Ridge, Colorado, J. Geophys. Res., 91, 53615370, 1986.

Platt, U.: The origin of nitrous and nitric acid in the atmosphere, in: Chemistry of Mutltiphase Atmospheric System, edited by: Jäschke, W., Spring-Verlag, New York, 299-319, 1986.

Qi, B., Kanaya, Y., Takami, A., Hatakeyama, S., Kato, S., Sadanaga, Y., Tanimoto, H., and Kajii, Y.: Diurnal peroxy radical chemistry at a remote coastal site over the sea of Japan, J. Geophys. Res., 112(D17), D17306, doi:10.1029/2006JD008236, 2007.

Ren, X. R., Brune, W. H., Canterll, C. A., Edwards, G.. D., Shirley, T., Metcalf, A. R., and Lesher, L. R.: Hydroxyl and peroxy radical chemistry in a rural area of Central Pennsylvania: Observations and model comparisons, J. Atmos. Chem., 52, 231-257, 2005.

Ritter, J. A., Stedman, D. H., and Kelly, T. J.: Ground-level measurements of nitric oxide, nitrogen dioxide and ozone in rural air, in: Nitrogenous Air Pollutants: Chemical and Biological Implications, edited by: Grosjean, D., Butterworth, Stoneham, Mass., 1979.

Salisbury, G., Monks, P. S., Bauguitte, S., Bandy, B. J., and Penkett, S. A.: A seasonal comparison of the ozone photochemistry in clean and polluted air masses at Mace Head, Ireland, J. Atmos. Chem., 41, 163-187, 2002.

Sander, S. P., Friedl, R. R., Golden, D. M., Kurylo, M. J., Huie, R. E., Orkin, V. L., Moortgat, G. K., Ravishankara, A. R., Kolb, C. E., Molina, M. J., and Finlayson-Pitts, B. J.: Chemical kinetics and photochemical data for use in stratospheric modeling, evaluation number 14, JPL Publication 02-25, NASA Jet Propulsion Laboratory, Pasadena, California, 2003.

Sillman, S., Logan, J. A., and Wofsy, C. S.: The sensitivity of ozone to nitrogen oxides and hydrocarbons in regional ozone episodes, J. Geophys. Res., 95(D2), 1837-1851, 1990.

Sillman, S.: The use of $\mathrm{NO}_{\mathrm{y}}, \mathrm{H}_{2} \mathrm{O}_{2}$, and $\mathrm{HNO}_{3}$ as indicator for ozone- $\mathrm{NO}_{\mathrm{x}}$-hydrocarbon sensitivity in urban locations, J. Geophys. Res., 100(D7), 14175-14188, 1995.

Stockwell, W. R., Kirchner, F., Kuhn, M., and Seefeld, S.: A new mechanism for regional atmospheric chemistry modeling, J. Geophys. Res., 102, 25847-25879, 1997.

Tan, D., Faloona, I., Simpas, J. B., Brune, W., Shepson, P. B., Couch, T. L., Sumner, A. L., Carroll, M. A., Thornberry, T., Apel, E., Riemer, D., and Stockwell, W.: $\mathrm{HO}_{\mathrm{x}}$ budget in a deciduous forest: Results from the PROPHET summer 1998 campaign, J. Geophys. Res., 106, 24407-24427, 2001.

Tanimoto, H., Kajii, Y., Hirokawa, J., Akimoto, H., and Minko, N. P.: The atmospheric impact of boreal forest fires in far eastern Siberia on the seasonal variation of carbon monoxide: Observa- 
tions at Rishiri, a northern remote island in Japan, Geophys. Res. Lett., 27, 4073-4076, 2000.

Thornton, J. A., Wooldridge, P. J., Cohen, R. C., Martinez, M., Harder, H., Brune, W. H., Williams, E. J., Roberts, J. M., Fehsenfeld, F. C., Hall, S. R., Shetter, R. E., Wert, B. P., and Fried, A.: Ozone production rates as a function of $\mathrm{NO}_{\mathrm{X}}$ abundances and $\mathrm{HO}_{\mathrm{x}}$ production rates in the Nashville urban plume, J. Geophys. Res., 107(D12), 4146, doi:10.1029/2001JD000932, 2002.

Tonnesen, G. S. and Dennis, R. L.: Analysis of radical propagation efficiency to assess ozone sensitivity to hydrocarbons and $\mathrm{NO}_{\mathrm{x}}$ : 1.Local indicators of instantaneous odd oxygen production sensitivity, J. Geophys. Res., 105, 9213-9225, 2000.
Trainer, M. E., Hsie,Y., McKeen, S. A., Tallamraju, R., Parrish, D. D., Fehsenfeld, F. C., and Liu, S. C.: Impact of natural hydrocarbons in hydroxyl and peroxy radicals at a remote site, J. Geophys. Res., 92, 11879-11894, 1987.

WMO - World Meteorological Organization: Scientific Assessment of Ozone Depletion: 1998, in Global Ozone Research and Monitoring Project Report, Rep. 44, Geneva, ISBN: 92-807-1722-7, 1999. 